\title{
Global modeling studies of composition and decadal trends of the Asian Tropopause Aerosol Layer
}

\author{
Adriana Bossolasco ${ }^{1}$, Fabrice Jegou ${ }^{1}$, Pasquale Sellitto ${ }^{2}$, Gwenaël Berthet $^{1}$, Corinna Kloss ${ }^{1}$, and Bernard Legras ${ }^{3}$ \\ ${ }^{1}$ Laboratoire de Physique et Chimie de l'Environnement et de l'Espace, CNRS/Université d'Orléans, \\ UMR 7328, Orléans, France \\ ${ }^{2}$ Laboratoire Interuniversitaire des Systèmes Atmosphériques, UMR CNRS 7583, IPSL, Université Paris-Est \\ Créteil/Université de Paris, Créteil, France \\ ${ }^{3}$ Laboratoire de Météorologie Dynamique, UMR CNRS 8539, IPSL, ENS-PSL/Sorbonne Université//École \\ Polytechnique, Paris, France
}

Correspondence: Adriana Bossolasco (adriana.bossolasco@cnrs-orleans.fr)

Received: 6 July 2020 - Discussion started: 11 August 2020

Revised: 8 January 2021 - Accepted: 11 January 2021 - Published: 24 February 2021

\begin{abstract}
The Asian summer monsoon (ASM) traps convectively lifted boundary layer pollutants inside its uppertropospheric lower-stratospheric Asian monsoon anticyclone (AMA). It is associated with a seasonal and spatially confined enhanced aerosol layer, called the Asian Tropopause Aerosol Layer (ATAL). Due to the dynamical variability of the AMA, the dearth of in situ observations in this region, the complexity of the emission sources and of transport pathways, knowledge of the ATAL properties in terms of aerosol budget, chemical composition, as well as its variability and temporal trend is still largely uncertain. In this work, we use the Community Earth System Model (CESM 1.2 version) based on the coupling of the Community Atmosphere Model (CAM5) and the MAM7 (Modal Aerosol Model) aerosol module to simulate the composition of the ATAL and its decadal trends. Our simulations cover a long-term period of 16 years from 2000 to 2015 . We identify a typical "doublepeak" vertical profile of aerosols for the ATAL. We attribute the upper peak (around $100 \mathrm{hPa}$, predominant during early ATAL, e.g., in June) to dry aerosols, possibly from nucleation processes, and the lower peak (around $250 \mathrm{hPa}$, predominant for a well-developed and late ATAL, e.g., in July and August) to cloud-borne aerosols associated with convective clouds. We find that mineral dust (present in both peaks) is the dominant aerosol by mass in the ATAL, showing a large interannual variability but no long-term trend, due to its natural variability. The results between 120 and $80 \mathrm{hPa}$ (dry aerosol peak) suggest that for aerosols other than dust
\end{abstract}

the ATAL is composed of around $40 \%$ of sulfate, $30 \%$ of secondary and $15 \%$ of primary organic aerosols, $14 \%$ of ammonium aerosols and less than $3 \%$ of black carbon. Nitrate aerosols are not considered in MAM7. The analysis of the anthropogenic and biomass burning aerosols shows a positive trend for all aerosols simulated by CESM-MAM7.

\section{Introduction}

During boreal summer, major convective activity is driven by the Asian summer monsoon (ASM). The ASM-related convection combines both land convection over mainland Asia and maritime convection over surrounding seas. This dynamical mechanism acts as a pathway for the transport of trace gases and pollutants from the boundary layer to the UTLS (Upper Troposphere Lower Stratosphere) (Randel and Park, 2006; Park et al., 2007; Pan et al., 2016; Gottschaldt et al., 2017). The upper atmospheric circulation is dominated by the related Asian monsoon anticyclone (AMA), which is known to contain enhanced concentration of tropospheric trace gases and aerosols (Randel and Park, 2006; Park et al., 2007, 2008), due to rapid lifting from the boundary layer by deep convection and subsequent horizontal confinement. The AMA is confined by the subtropical westerly jet stream in the north $\left(\sim 40-45^{\circ} \mathrm{N}\right)$ and the equatorial easterly jet stream in the south $\left(\sim 10-15^{\circ} \mathrm{N}\right)$ and spans from about 20 to $140^{\circ} \mathrm{E}$ in the Northern Hemisphere. The alti- 
tude of maximum strength of the anticyclonic circulation is around the local tropopause $(17-18 \mathrm{~km})$ (e.g., Dethof et al., 1999; Bian et al., 2012; Ploeger et al., 2015; Garny and Randel, 2016; Pan et al., 2016; Brunamonti et al., 2018). On a daily basis, the specific location, spatial extent and strength of the AMA depend on the internal dynamical variability of the ASM (Randel and Park, 2006; Garny and Randel, 2013; Vogel et al., 2015; Pan et al., 2016). As suggested, the AMA can effectively trap boundary layer pollutants and is associated with the formation of the Asian Tropopause Aerosol Layer (ATAL) (Vernier et al., 2011, 2015). The ATAL refers to an enhanced aerosol layer near the tropopause over the Asian monsoon region extending from $\sim 13$ to $\sim 18 \mathrm{~km}$ altitudes. Its horizontal extension is determined by the AMA geometry, roughly in the broad region bounded by approximately $5-105^{\circ} \mathrm{E}, 15-45^{\circ} \mathrm{N}$ (e.g., Vernier et al., 2015; Lau et al., 2018; Bian et al., 2020). Combined satellite observations from SAGE (Stratospheric Aerosol and Gas Experiment) II and CALIOP (Cloud-Aerosol LIDAR with Orthogonal Polarization) have highlighted the presence of the ATAL since 1998 (Vernier et al., 2015). Höpfner et al. (2019) revealed the presence of ammonium nitrate aerosols inside the AMA in August 1997 from CRISTA (Cryogenic Infrared Spectrometers and Telescopes for the Atmosphere) satellite observations. Model studies have suggested that the ATAL might have been present previously but was masked by the overwhelming UTLS aerosols produced by the Mount Pinatubo eruption (Neely et al., 2014).

The sources, chemical composition and spatial and temporal variability of the ATAL are not yet well understood. Recent observations from the StratoClim (Stratospheric and upper tropospheric processes for better climate predictions) aircraft campaign in 2017 and a few recent balloon measurements from the BATAL (Balloon measurement campaigns of the Asian Tropopause Aerosol Layer) 2015 campaign suggest that aerosol particles in the ATAL may contain large amounts of sulfate as well as organics, nitrates (including ammonium nitrate), black carbon and dust (Vernier et al., 2015, 2018; Höpfner et al., 2019). Different indications on the ATAL composition have been given by a number of modeling studies. Fadnavis et al. (2013), using the aerosolchemistry-climate model ECHAM5-HAMMOZ, studied the transport of aerosols to the UTLS and showed persistent maxima in black carbon, organic carbon, sulfate, and mineral dust aerosols within the anticyclone throughout the ASM (from July to September). Yu et al. (2015), using the CESM1 (Community Earth System Model) global Earth system model coupled with the CARMA (Community Aerosol and Radiation Model for Atmospheres) aerosol model, suggested that the ATAL might be principally composed of secondary organic and sulfate aerosols as well as of primary organic aerosols. Fadnavis et al. (2017) performed model simulations with the ECHAM6-HAM (European Centre Hamburg Model 6.3-Hamburg Aerosol Model) global aerosolclimate model, and their simulations showed a persistent maximum of carbonaceous aerosols in the ATAL region. Ma et al. (2019), using the ECHAM/MESSy (Modular Earth Submodel System) for the Atmospheric Chemistry (EMAC) general circulation model coupled with the Global Modalaerosol eXtension (GMXe) aerosol module, found that mineral dust and water-soluble compounds, like nitrate and sulfate, are the principal typology of aerosols over the Tibetan Plateau, within the AMA. Using the GEOS-Chem (Goddard Earth Observing System with Chemistry) chemical transport model, Fairlie et al. (2020) found significant amounts of sulfate, ammonium, organic aerosols and nitrate in the ATAL, with a predominant contribution of nitrate, as was identified previously by $\mathrm{Gu}$ et al. (2016) using an earlier version of the model. Therefore, existing modeling studies have proven able to simulate the enhanced concentration of aerosols in the AMA region, even if a very large uncertainty in the composition of the ATAL remains.

In several studies, dust has been shown to be a major contributor to the aerosol burden in the Asian upper troposphere during summer. Xu et al. (2015), using CALIOP and MISR (Multi-angle Imaging SpectroRadiometer) satellite data, found that dust is one of the predominant aerosols over the Tibetan Plateau, most probably originating from the Taklamakan desert and lofted from the surface to an altitude of about $10 \mathrm{~km}$. Ma et al. (2019) simulated a broad maximum of dust surface concentration at the northern edge of the Tibetan Plateau up to $10 \mathrm{~km}$. Their model results showed that the enhancement of dust aerosols is still visible up to $16 \mathrm{~km}$ above the Tibetan Plateau, with a maximum shifted to the east and south as a consequence of the influence of anticyclonic circulation. Large amounts of dust have also been reported by Lau et al. (2018) in the mid and upper troposphere over India and China from May to June transported from the Middle East desert and then from July to August trapped and accumulated within the AMA and contributing to the ATAL formation.

A rising temporal trend of the ATAL optical signature in the AMA region has been observed (Vernier et al., 2015). The recent rising trends of sulfur dioxide and volatile organic compounds emissions in India have been proposed as a candidate for explaining the appearance of the ATAL and its evolution. Continental convective regions have also been shown to be the main contributors to the air trapped within the AMA with northern India and south of the Tibetan Plateau as specific source areas (e.g., Tissier and Legras, 2016; Legras and Bucci, 2020). Bergman et al. (2013), using Lagrangian backward trajectories, showed that the anticyclone is connected to the boundary layer through a vertical conduit centred over northeastern India, Nepal, and southern Tibet. In the recent BATAL campaign, Vernier et al. (2018) used backtrajectory calculations to point at the north of India as a principal region source for the ATAL. Lau et al. (2018), based on MERRA-2 reanalysis, reported that the Himalayas Gangetic Plain (HGP) region and the Sichuan Basin (SB) of southwestern China are two important regions with strong vertical 
transport of $\mathrm{CO}$, carbonaceous aerosols and dust from the surface to the UTLS. On the other hand, the simulations of Fairlie et al. (2020) suggested that the anthropogenic sources from India contribute up to $40 \%$ of sulfate and up to $65 \%$ of organic and ammonium aerosols in the western ATAL region, whereas China contributes up to $60 \%$ (both sulfate and organic aerosols) in the eastern ATAL region.

It is also important to note that the ATAL formation and possible spatial and temporal variability are closely related to the dynamical variability of the AMA. For example, Basha et al. (2020) suggested that the spatial extent and strength of the AMA are greater during July and August compared to June and September and that the decadal variability is bigger at the edges of the anticyclone. As a consequence of the variability of atmospheric dynamics, some years show a stronger monsoon activity than others (Lau et al., 2018; Basha et al., 2020; Yuan et al., 2019), and this affects the ATAL formation, location and composition. Several studies have shown that the AMA exhibits intraseasonal variability between the Iranian Plateau and the Tibetan Plateau with a quasi-biweekly oscillation (e.g., Zhang et al., 2002; Yan et al., 2011; Nützel et al., 2016; Pan et al. 2016; Wei et al., 2019).

This study provides further insight into the chemical composition of the ATAL and assesses its decadal variability composition and aerosol trends for the first time. To assess this, we have carried out long-term modeling of the ATAL using the Community Earth System Model (CESM 1.2), which embeds the Community Atmosphere Model (CAM5) coupled with the MAM7 (Modal Aerosol Model) aerosol module. Our simulations cover an overall extended period of 16 years, from 15 January 2000 to 15 December 2015. Yuan et al. (2019) derived decadal trends for carbonaceous aerosols and dust in the ATAL using only meteorological reanalysis data, while in the present study a detailed chemistry and microphysical modeling is used to estimate trends for a more comprehensive set of aerosol compositions.

The present paper is structured as follows. In Sect. 2, we describe the model and correlative data used for its validation. The validation is discussed in Sect. 3. Results are presented and discussed in Sect. 4. Conclusions are drawn in Sect. 5.

\section{Model set-up and satellite observations}

\subsection{The CESM-MAM7 model}

Model simulations were performed using the global Community Earth System Model (CESM1.2), based on the Community Atmospheric Model (CAMS 5.1) with its full chemical core for both troposphere and stratosphere, coupled with the Modal Aerosol Model (MAM7). The MAM7 module treats the aerosol microphysics, size distribution and both internal and external mixing using seven modes. The seven modes are, specifically, accumulation (a1), Aitken (a2), primary car- bon (a3), fine dust and sea salt (a5 and a4), and coarse dust and sea salt (a7 and a6) (Liu et al., 2012). Extraterrestrial aerosols are neglected in our model. Table 1 lists the aerosols and dry diameter size ranges of each mode. The size distributions of each mode are assumed to be log-normal.

The total number of transported aerosol tracers by the seven log-normal modes in MAM7 is 31. The transported precursor gas species are $\mathrm{SO}_{2}$ (sulfur dioxide), $\mathrm{H}_{2} \mathrm{O}_{2}$ (hydrogen peroxide), DMS (dimethyl sulfide), $\mathrm{H}_{2} \mathrm{SO}_{4}$ (sulfuric acid gas vapor), $\mathrm{NH}_{3}$ (ammonia) and lumped semi-volatile organic species (big alkenes, big alkanes, toluene, isoprene and monoterpenes).

Wet removal of soluble gas-phase species combines two processes: in-cloud, or nucleation scavenging (rainout), which is the local uptake of soluble gases and aerosols by the formation of initial cloud droplets and their conversion to precipitation, and below-cloud, or impaction scavenging (washout), which is the collection of soluble species from the interstitial air by falling droplets or from the liquid phase via accretion processes. The transfer of soluble gases into liquid condensate is calculated using Henry's law, assuming equilibrium between the gas and liquid phases. This is the standard scheme used in CAM5.1 (Lamarque et al., 2012), although as noted by Fairlie et al. (2020), a more physically based treatment of wet scavenging of $\mathrm{SO}_{2}$ in convective updrafts increases the amount of sulfate.

The MAM7 module explicitly treats the microphysics of sulfate $\left(\mathrm{SO}_{4}\right)$, ammonium $\left(\mathrm{NH}_{4}\right)$, sea salt, dust, black carbon (BC), primary organic matter (POM), and secondary organic aerosol (SOA). It simulates nucleation, condensation, coagulation, dry deposition, wet removal, and water uptake of aerosols. The formation of new particles by nucleation occurs in the Aitken mode, which is calculated using a ternary parameterization $\left(\mathrm{H}_{2} \mathrm{SO}_{4}-\mathrm{NH}_{3}-\mathrm{H}_{2} \mathrm{O}\right)$ and boundary nucleation (Merikanto et al., 2007). The inter- and intra-modal coagulation is calculated for Aitken, accumulation and primary carbon modes.

In MAM7 the aerosol particles (AP) can exist in the "interstitial" state (AP that are suspended in clear or cloudy air) and "cloud-borne" state (AP attached to or contained within different hydrometeors, such as cloud droplets and/or ice crystals). MAM7 distinguishes between cloud-borne aerosols that are within stratiform clouds and the interstitial aerosols which include both clear-sky AP and AP contained within convective clouds. This means that the AP in convective cloud droplets are lumped with the interstitial AP in the model, and the interstitial aerosol mixing ratios include the truly interstitial (i.e., "clear-sky/dry") AP and the "convective" cloud-borne AP.

As has been detailed in Wang et al. (2013), in CAM5MAM7 cloud-borne aerosols in stratiform clouds are treated in a prognostic way in CAM5: their mixing ratios are saved between model time steps and evolve as a result of source, sink, and transport processes. Their activation is parameterized using vertical velocity (resolved and sub-grid turbulent) 


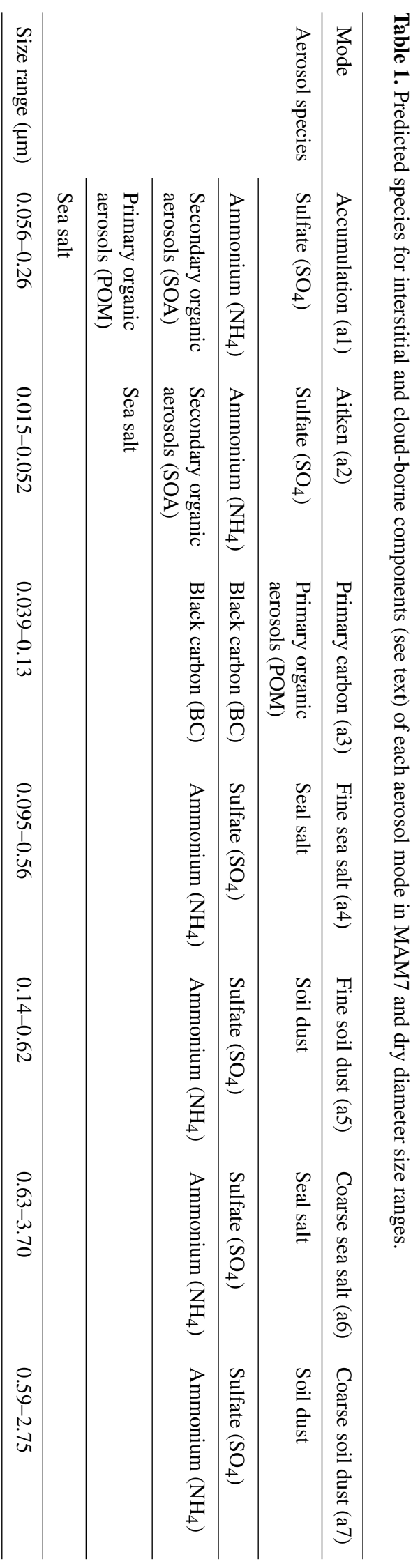

and aerosol properties of all the modes, following AbdulRazzak and Ghan (2000). The stratiform-cloud-borne AP are assumed to not interact with convective clouds. AP in convective clouds are treated diagnostically: their mixing ratios are diagnosed each model time step (with no "memory") from the interstitial aerosol mixing ratios.

Both interstitial and cloud-borne aerosol particles are subject to wet and dry removal deposition. CESM-MAM7 distinguishes between "in-cloud" and "below-cloud" wet removal. In-cloud wet removal involves activation of interstitial aerosol to become cloud-borne, followed by conversion of cloud droplets (and the cloud-borne aerosol particles) to precipitation. Below-cloud wet removal involves direct capture of interstitial aerosols by precipitation particles through a number of processes (e.g., inertial impaction, Brownian diffusion) and is relatively inefficient for aerosol in the accumulation mode size range. For a complete description of the CAM5-MAM7 model, see Liu et al. (2012).

In our configuration, land, sea ice, and rivers are interactive processes in CESM, whereas oceans are prescribed. The model horizontal grid resolution is $1.9^{\circ} \times 2.5^{\circ}$ in latitude $\times$ longitude and has 56 vertical levels of altitude extending from the surface to approximately $45 \mathrm{~km}$ altitude, with 30 levels in the troposphere and 10 levels in the UTLS, at a vertical resolution of approximately $1 \mathrm{~km}$.

The following emissions are used in our simulations. Biogenic emissions for $\mathrm{CO}$, isoprene, $\mathrm{C}_{2} \mathrm{H}_{4}, \mathrm{C}_{2} \mathrm{H}_{6}, \mathrm{C}_{3} \mathrm{H}_{6}$, $\mathrm{C}_{3} \mathrm{H}_{8}$, acetone, methanol and isoprene are taken from the MEGAN-MACC emission inventory (Sindelarova et al., 2014). Anthropogenic emissions and biomass burning emissions are based on the CMIP6 (Coupled Model Intercomparison Project Phase 6) inventories provided by the Community Emissions Data System (CEDS, http://www.globalchange. umd.edu/ceds/ceds-cmip6-data/, last access date: 1 September 2020). According to the CEDS, the anthropogenic emissions are first scaled to the EDGAR database for most emission species and then to national/regional inventories. For instance, REAS 2.1 (Regional Emission inventory in ASia version 2.1, Kurokawa et al., 2013) is the national inventory used in Asia, for $\mathrm{SO}_{2}, \mathrm{NO}_{x}$, NMVOCs, $\mathrm{CO}$ and $\mathrm{CH}_{4}$. For each inventory, scaling factors are calculated for years when inventory data are available. Where inventory data are not available over the specified scaling time frame, remaining scaling factors are interpolated and extended to provide a continuous trend (Hoesly et al., 2018). The goal of the scaling process is to match CEDS emission estimates with comparable inventories. The scaling process modifies CEDS default emissions and emission factors, possibly leading to an additional source of uncertainties.

The biomass burning emissions for CMIP6 are based on merged satellite observation and fire models (van Marle et al., 2017), using GFED4 (Global Fire Emissions Database version 4), which includes small-magnitude fires (available from 1997 to 2015). 
The emission of sea salt aerosols from the ocean follows the parameterization of Märtensson et al. (2003), for aerosols with a geometric diameter $<2.8 \mu \mathrm{m}$. For aerosols with a geometric diameter $\geq 2.8 \mu \mathrm{m}$, sea salt emissions follow the parameterization of Monahan et al. (1986). The emission of mineral dust particles is calculated based on the Dust Entrainment and Deposition Model (Zender et al., 2003). Volcanic $\mathrm{SO}_{2}$ emissions were obtained through the Volcanic Emissions for Earth System Models (VolcanEESM) initiative, described by Mills et al. (2016). The VolcanEESM database contains estimates of total $\mathrm{SO}_{2}$ emissions by volcanic eruptions over the 1850-2016 period.

The meteorology in the model has been nudged using MERRA2 (Modern-Era Retrospective analysis for Research and Applications, Version 2, https://rda.ucar.edu/datasets/ ds313.3, last access date: 11 September 2020) data with a weight factor of 0.1 towards the reanalysis, for temperature and wind fields every $6 \mathrm{~h}$ for the years 2000-2015.

In the standard configuration of CESM-MAM7 the vertical transport of interstitial aerosols and trace gases by deep convective clouds uses updraft and downdraft mass fluxes from the Zhang-McFarlane parameterization (Zhang and McFarlane, 1995). Currently this vertical transport is calculated separately from wet removal. Cloud-borne aerosols associated with large-scale stratiform clouds are assumed to not interact with the convective clouds.

Vertical transport by shallow convective clouds is treated similarly, using mass fluxes from the Park and Bretherton (2009) shallow convection parameterization.

We run our simulations for 16 years, from 15 January 2000 to 15 December 2015, using the CESM1.2 (CAM5) initial atmosphere state file at that date.

\subsection{Correlative satellite data}

Our simulations have been compared to satellite data from the Microwave Limb Sounder (MLS) and the Atmospheric Chemistry Experiment-Fourier Transform Spectrometer (ACE-FTS).

The MLS was launched in July 2004 onboard the NASA Aura satellite. Measurements in the millimeter and submillimeter wavelength ranges are continuously made during both night and day every $165 \mathrm{~km}$ along the suborbital track, covering latitudes from $82^{\circ} \mathrm{S}$ to $82^{\circ} \mathrm{N}$ (Waters et al., 2006). Here, we use the MLS version 4.23 data set (Livesey et al., 2020) for CO (Pumphrey et al., 2007; Livesey et al., 2008) for selected years (2005 and 2008) and pressure levels in the UTLS. We use CO vertical profiles from 215 to $0.0046 \mathrm{hPa}$. For these pressure levels, the vertical resolution is about $5.1 \mathrm{~km}$ and the horizontal resolution about $570 \mathrm{~km}$ (at $147 \mathrm{hPa}$ ) (Livesey et al., 2020). The data precision is about $16 \mathrm{ppbv}$, and the data accuracy is estimated at $\pm 26 \mathrm{ppbv}$ and $\pm 30 \%$.

The ACE-FTS instrument is an infrared solar occultation spectrometer, providing profiles of the Earth since Febru- ary 2004 from the Canadian satellite SCISAT-1 (Bernath et al., 2005). It operates in the wavelength range from 2.2 to $13.3 \mu \mathrm{m}\left(750-4400 \mathrm{~cm}^{-1}\right)$ with a spectral resolution of $0.02 \mathrm{~cm}^{-1}$. The data set provides 30 measurements per day for over 30 chemical species from $5 \mathrm{~km}$ (or cloud top) up to $150 \mathrm{~km}$. The horizontal weighting function of a measurement typically has a width of $\sim 300 \mathrm{~km}$. The vertical resolution is $<4 \mathrm{~km}$.

\section{Model comparison with satellite observations: CO distribution}

We compare CO measurements from MLS and ACE-FTS with our simulations. While a direct comparison of aerosol extinction observations from various satellite instruments with CESM-MAM7 is not easy, e.g., due to the interference of clouds, using a trace gas (like CO) is a more straightforward approach for a comparison. In fact, three-dimensional summer distributions of $\mathrm{CO}$ show a distinct enhancement in the AMA and have proven an ideal tracer to identify the AMA's location and to track the transport processes to the AMA (e.g., Park et al., 2008; Barret et al., 2016; Santee et al., 2017). The CO comparison enables a test of the model's capacity to reproduce the large-scale dynamical and morphological features, which is related to the aerosol distribution.

Figure $1 \mathrm{a}$ and $\mathrm{b}$ show the average summer (June-JulyAugust) CO distribution, for the year 2008, observed by MLS in the UTLS (Fig. 1a) and produced by CESM-MAM7 (Fig. 1b), at the pressure level of $147 \mathrm{hPa}$, for MLS, and $150 \mathrm{hPa}$ (average between 160 and $140 \mathrm{hPa}$, three levels), for CESM-MAM7. The locations of the general enhancement of $\mathrm{CO}$ mixing ratios in the AMA and of the absolute maximum above India are well reproduced by the model (i.e., they are consistent with MLS observations). It should be noted that the pressure levels used in this comparison, for CESMMAM7 and MLS, are not exactly identical. In addition, the vertical resolutions differ as well (about $5.1 \mathrm{~km}$, for MLS, and about $1 \mathrm{~km}$, for CESM-MAM7). Furthermore, the temporal samplings of satellite and model data also differ: for CESM-MAM7 the temporal sampling is twice a day (noon and midnight), whereas MLS samples the Earth on distinct orbits, with a full global coverage every $3 \mathrm{~d}$. Even though it is therefore possible that intensive short-time events are missed by either CESM-MAM7 or MLS, the sampling bias is not expected to present a significant source of discrepancies for 3-month averages, as shown in Fig. 1a and b.

Compared to MLS observations, the model underestimates the $\mathrm{CO}$ mixing ratio by about $30 \%$. One possible reason for this underestimation could be an underestimation of biomass burning emissions in the model (obtained from GFED4), which are a significant source of $\mathrm{CO}$. We have also compared CESM-MAM7 HCN mixing ratios (a strong biomass burning tracer) with ACE-FTS HCN observations (comparison not shown here). This latter comparison shows a marked un- 
derestimation of modeled $\mathrm{HCN}$ amounts, which supports the hypothesis of an underestimation of biomass burning emissions. Stroppiana et al. (2010) compared different biomass burning inventories for CO. For 2003, they found that the $\mathrm{CO}$ emissions range from $365 \mathrm{Tg}$ (GFED3) to $1422 \mathrm{Tg}$ (VGT - Vegetation Emission Inventory, CNRS-LA) (Tansey et al., 2008), with GFED at the low end of this variability. Unlike GFED3, GFED4 includes upgrades like the inclusion of small fire-burned areas and a revised fuel consumption parameterization that causes global emissions to increase in comparison with the previous version. However, the effects of these adjustments vary spatially and, in particular regions like the southeast of Asia or the north and south of Africa, the CO biomass burning emissions are lower (see Van de Werf et al., 2017). This could explain the low bias in CO mixing ratios for our comparisons with satellite measurements. On the other hand, as mentioned in Sect. 2.1, the CEDS anthropogenic inventory uses a scaling process to match the CEDS emissions estimates with available inventories. In the case of anthropogenic emissions for $\mathrm{CO}$, the last year from local inventories available is 2008 in Asia (from REAS) and 2010 in China (from the MEIC-Multi-resolution Emission Inventory for China). As a result, the extrapolation during 2010-2015 may be an additional source of uncertainties for comparisons with observations over this period.

While reproducing monthly average features is a probing test for our simulations, catching shorter-term processes and variability is even more challenging towards the description of a complex phenomenon as the ATAL. Thus, we have also tested the model's ability to reproduce observed daily specific features. Figure $1 \mathrm{c}$ shows a $3 \mathrm{~d}$ average from 4 to 6 July 2005. During this short time period, a multi-centric AMA is observed by MLS, with rather multiple maxima in eastern Asia, instead of a classical individual maximum above the Himalayan region. Our CESM-MAM7 simulations reasonably reproduce this pattern. They show a distributed pattern with maxima above eastern Asia but also above western Asia (Fig. 1d), which is very consistent with MLS observations (Fig. 1c). For $3 \mathrm{~d}$ averages the sampling bias can play a significant role in explaining the different patterns observed for MLS and CESM-MAM7. Therefore, some shortterm features might not have been captured by the MLS instrument. Nevertheless, our simulations are very consistent with MLS observations for this short-term configuration.

We have also tested the vertical structures of CESMMAM7 simulations, using an ACE-FTS CO mixing ratio profile in the UTLS (Fig. 1e). Observations with ACE-FTS have been chosen because of their better vertical resolution with respect to MLS. It has to be noted that the location and time of the ACE-FTS measurement profile and the model output are not exactly the same but agree within $1^{\circ}$ longitude, $4^{\circ}$ latitude and within $2.5 \mathrm{~h}$ (see Fig. 1e). The vertical distribution of CESM-MAM7 simulations shows a quite remarkable agreement with ACE-FTS observations above $200 \mathrm{hPa}$. Up to the level of $\sim 400 \mathrm{hPa}$ the model underestimates (as also shown for the previous examples with MLS; see Fig. 1ad) $\mathrm{CO}$ values by around $30 \%$, with smaller underestimations between 400 and $200 \mathrm{hPa}$. For pressure levels lower than $180 \mathrm{hPa}$ CESM-MAM7 and ACE-FTS show a remarkable consistency. Model underestimations of $\mathrm{CO}$ vertical concentrations have already been reported in previous studies with other models (e.g., Barret et al., 2016). The discrepancies observed between simulated and observed CO could be linked to the treatment of convection by CESM1/CAM5 together with discrepancies in emission inventories (see discussion above). In the work of He et al. (2015) underestimations of surface CO by CESM1/CAM5 have been reported especially over Asia, while the global tropospheric column of CO seems to be overestimated in their study. These authors suggest uncertainties in terms of spatial allocations of $\mathrm{CO}$ emissions as well as convective transport treatments. The model resolution used could also impact the calculated transport of gases by convection. Brühl et al. (2018) reported this fact for the transport of aerosols in their study. In our work with CESMMAM7, we use a $1.9 \times 2.5^{\circ}$ horizontal resolution and 56 vertical levels, which is a standard configuration for CESM1 and has been used in previous studies of aerosol properties (Yu et al., 2015, 2017).

Because of the sparse sampling of ACE-FTS data in the AMA, we have provided an additional comparison of the monthly vertical distribution of $\mathrm{CO}$ for the whole year of 2008 between MLS data and modeled CO (Fig. S1). The comparison, while showing an underestimation of the modeled vertical amounts of CO, especially below the $150 \mathrm{hPa}$ level, presents spatial distributions of $\mathrm{CO}$ which are in good agreement.

The comparison of simulated CO with observed MLS and ACE-FTS CO in the UTLS allows us to conclude that, except for a possible underestimation of $\mathrm{CO}$ emissions, the model is able to reproduce the position and spatial extent of the Asian monsoon anticyclone in our simulations.

\section{Results and discussions}

\subsection{Aerosol distribution and composition}

Figure 2 shows the CESM-MAM7 regional distribution, over an extended area centered around the AMA region, of different aerosol types: sulfate, SOA, POM, BC, ammonium and mineral dust. The accumulation mode (a1) is shown here for all aerosol types, except for mineral dust (for which fine soil dust mode (a5) is shown). These maps represent average aerosol concentrations, for July-August 2014, at three different pressure levels: 120,100 and $80 \mathrm{hPa}$, respectively (approximately 15.0, 16.5 and $18.0 \mathrm{~km}$ ). Concentrations of sea salt particles, also modeled in our study, are negligible and therefore are not shown in Fig. 2. The model reproduces the horizontal distribution of the ATAL, i.e., an increase in aerosol concentration in the AMA region with el- 
(a) MLS CO JJA 2008: $147 \mathrm{hPa}$

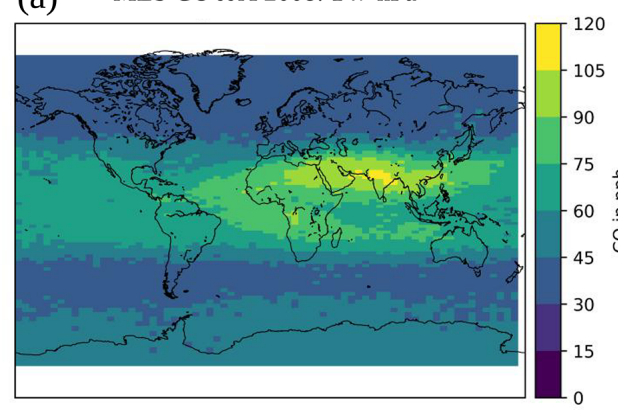

(c) MLS CO 4 to 6 July 2005: $147 \mathrm{hPa}$

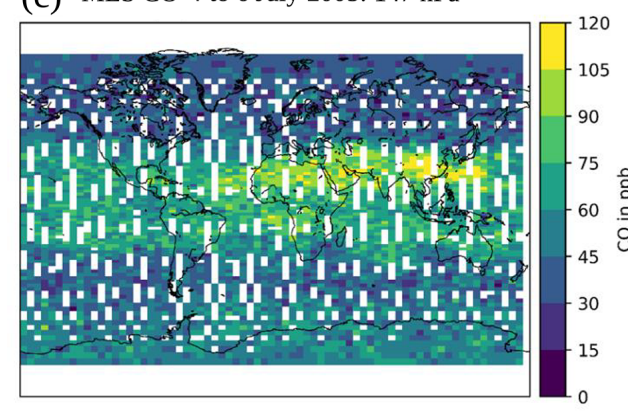

(b) CESM-MAM7 CO JJA 2008: 140-160 hPa

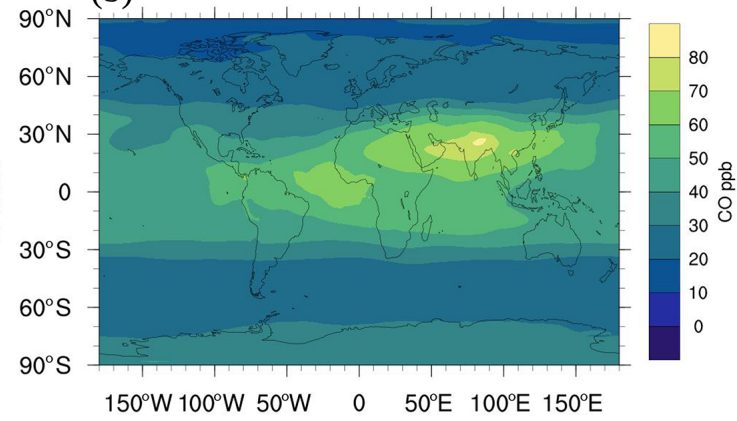

(d) CESM-MAM7 CO 4 to 6 July 2005: 140-160 hPa

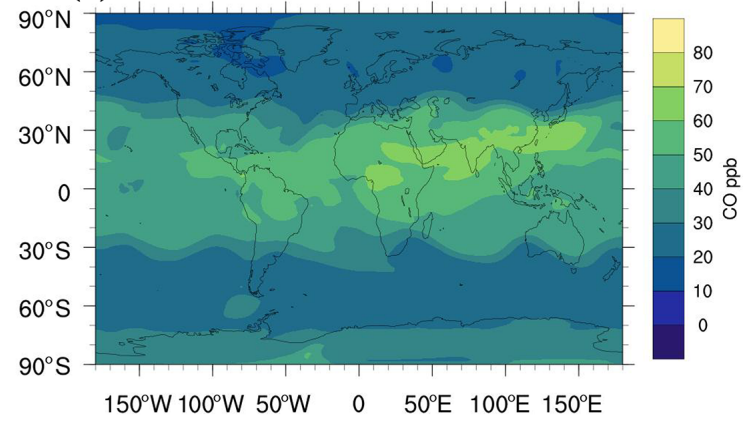

(e) CO CESM-MAM7 and ACE-FTS comparison 07/08/2014

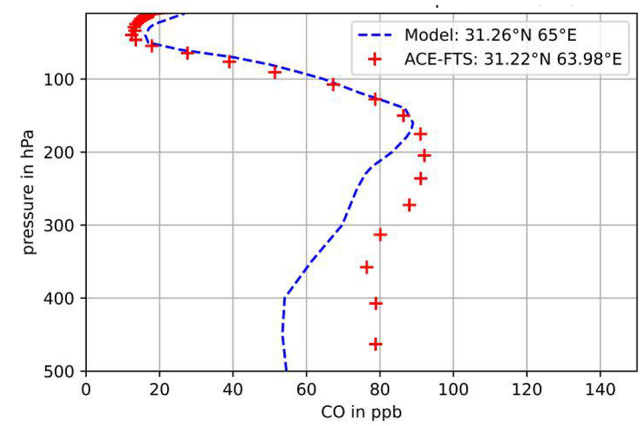

Figure 1. (a) Average MLS CO mixing ratio distribution for June-July-August 2008 at 147 hPa pressure level and (b) average CESMMAM7 CO mixing ratio distribution for June-July-August 2008 between 140 and $160 \mathrm{hPa}$. (c) Three-day average for the MLS CO mixing ratios at $147 \mathrm{hPa}$ (4 to 6 July 2005) and (d) respective CESM-MAM7 simulations, for 4 to 6 July 2005 between 140 and $160 \mathrm{hPa}$. (e) ACEFTS and CESM-MAM7 vertical CO profiles for 7 August 2014 at $31.22^{\circ} \mathrm{N}-63.98^{\circ} \mathrm{E}, 14: 30 \mathrm{UTC}$ and $31.26^{\circ} \mathrm{N}, 65.00^{\circ} \mathrm{E}$, and $12: 00 \mathrm{UTC}$, respectively.

evated aerosol concentration at $120-100 \mathrm{hPa}$ (upper troposphere) and noticeably decreasing for pressures lower than $80 \mathrm{hPa}$ (altitudes higher than $18.0 \mathrm{~km}$, lower stratosphere).

Figure 2 shows that dust is the principal aerosol species in the ATAL, in terms of mass concentration, in our simulations. These results agree with some previous modeling studies (e.g., Fadnavis et al., 2013; Ma et al., 2019). Our results show an aerosol dust concentration at $100 \mathrm{hPa}$ of about $100 \mathrm{ng} \mathrm{m}^{-3}$ in agreement with the findings of Ma et al. (2019), who reported a value $>100 \mathrm{ng} \mathrm{m}^{-3}$ at $16 \mathrm{~km}$ with ECHAM/MESSy. Fadnavis et al. (2013) using the ECHAM5-HAMMOZ model simulated a value of $\sim 30 \mathrm{ng} \mathrm{m}^{-3}$ for dust, similarly to Fairlie et al. (2020), who reported a concentration of $\sim 20 \mathrm{ng} \mathrm{m}^{-3}$ using the GEOSChem model. According to Lau et al. (2018), high burdens of dust are found in the ASM region, transported from the desert regions which are trapped by local topography and accumulated to high concentration over the southern and eastern foothills of the Tibetan Plateau and transported to the ATAL $(\sim 12-16 \mathrm{~km})$ region by increased vertical motion associated with deep convective motions. It is not clear whether processes that drive convection and have an impact on its modeling (convective schemes, model resolutions, reanalyses used to nudge the models), accounted for in the abovementioned model studies, can explain the differences in terms of simulated amount of dust. For instance, Brühl et al. (2018) showed 
that the amounts of dust reaching the UTLS region in the EMAC model are sensitive to model resolution, showing that a resolution of $1.88 \times 1.88^{\circ}$ and 90 vertical levels has the best fits with spaceborne observations of dust extinction. In our work with CESM-MAM7, we use a $1.9 \times 2.5^{\circ}$ horizontal resolution and 56 vertical levels, which is one of the standard configurations for CESM1 and has been used in previous studies of aerosol properties (e.g., Yu et al., 2015, 2017). These resolutions are lower than those in Brühl et al. (2018), and this could impact the amount of dust reaching the UTLS in CESM-MAM7 as a result of differences in convection top height and overshooting convection.

In addition, Wu et al. (2019), using CESM1-CAM5 with the default scheme for the dust emissions (Zender et al., 2003), the same scheme used in the present study, showed that the model overestimates dust extinction over the Taklamakan and Gobi deserts during the summer period. Such high biases in dust extinction have been attributed to excessive convective transport, lack of secondary activation of aerosol entrained into convective updrafts and strong dust transport in the upper troposphere from Africa and the Middle East. These hypotheses, together with differences in the model resolution, could explain the higher dust amounts in our CESM-MAM7 simulations, which use the same default scheme for the generation of dust.

The discrepancies observed between different models could also result from the different schemes used for the dust lifting as well as the sensitivity of dust release to surface conditions, particularly to surface winds and soil properties.

Other main aerosol components contributing to the ATAL in our simulations are sulfates, followed by SOA, POM, ammonium and to a lesser extent BC. Yu et al. (2015), using the CESM1/CARMA model, suggested that the ATAL (at altitude levels between 230 and $100 \mathrm{hPa}$ ) is principally composed of organics $(\sim 60 \%)$ and sulfates $(\sim 40 \%)$, while an aerosol enhancement due to dust above Africa was also observed. Fadnavis et al. (2013) found that the dominating aerosol types in the ATAL are dust and sulfates, followed by organic carbon and BC aerosols. Fairlie et al. (2020) also simulated that sulfate and primary organic aerosols are major components of the ATAL but, as in the work of Gu et al. (2016), with nitrate as the predominant aerosol.

As discussed in previous studies, the spatial extent, strength and position of the AMA are highly variable due to the dynamical seasonal variability of the ASM (e.g., Randel and Park, 2006; Garny and Randel, 2013; Lau et al., 2018; Basha et al., 2020). Due to this dynamical variability, the tracer concentrations are strongly controlled by the oscillations and shedding of the AMA that therefore affect the ATAL extent and composition. In order to determine the aerosol burden within the ATAL, we have defined a simple criterion to isolate the ATAL horizontal extent, i.e., where there is a high probability of finding AMA air masses, based on a threshold on the geopotential height (GPH) values. Similar empirical selections of high GPH values to represent an- ticyclone boundaries have been used in a number of previous works, e.g., Highwood and Hoskins (1998), Bergman et al. (2013), Barret et al. (2016), and Pan et al. (2016). For the subsequent analysis, we identify the AMA region based on GPH values higher than $16.7 \mathrm{~km}$ at $100 \mathrm{hPa}$. Based on this criterion, a wide region from around $20-130^{\circ} \mathrm{E}$ and 20 $45^{\circ} \mathrm{N}$ is generally selected. Then, we define a static box corresponding to the highest probability of finding air masses delimited by the anticyclone. According to these considerations, we have finally chosen to restrict the box to $20-35^{\circ} \mathrm{N}$ and $60-100^{\circ} \mathrm{E}$ to identify and study the ATAL composition (blue box in the central panel of the first row in Fig. 2).

\subsection{Vertical distribution of the ATAL}

In Fig. 3 we show CESM-MAM7 vertical aerosol mass mixing ratio profiles for the accumulation mode, averaged from June to August within the blue box of Fig. 2, for 2 selected years, 2000 and 2014. Our focus on the accumulation mode is justified by the fact that it is the principal mode that contributes to the ATAL (see Fig. S2 in Supplement), with mostly anthropogenic origin. In this first analysis, we have excluded dust. Dust is still the most important ATAL component, in our simulations, in terms of mass, but its burden and variability are mostly subject to natural factors and their variability.

A vertical region with marked localized increase in the concentrations of all the aerosol types is observed between 300 and $80 \mathrm{hPa}$. This is what is expected as a manifestation of the ATAL, as it is broadly the vertical region where the AMA is located. The vertical structure of the AMA-related dynamics has been investigated by several authors (e.g., Park et al., 2009; Bergman et al., 2013; Garny and Randel, 2013; Brunamonti et al., 2018; Bian et al., 2020), showing evidence of deep convection and confinement extending up to 1.5$2.0 \mathrm{~km}$ above the cold-point tropopause. Enhanced aerosol backscatter also reveals the signature of the ATAL over the same altitude range (Vernier et al., 2015; Brunamonti et al., 2018). This location suggests that the existence of the layer is tied to a large-scale vertical transport in the anticyclone, i.e., around 200 to $80 \mathrm{hPa}(\sim 13$ to $18 \mathrm{~km})$ depending on the location and time.

Our simulations show a characteristic "double-peak" vertical configuration with two relative maxima, one at higher altitudes $(\sim 80-120 \mathrm{hPa})$ and the other at lower altitudes $(\sim 200-300 \mathrm{hPa}$ ). During early phases of the ASM (e.g., June, Fig. 3a) the maximum of aerosol concentrations is generally located between 200 and $80 \mathrm{hPa}$; later on (e.g., July and August, Fig. 3c, e) an aerosol enhancement at lower altitudes (around $250 \mathrm{hPa}$ ), superimposed with a maximum at around $100 \mathrm{hPa}$, is found. This "double-peak" vertical structure could be explained by looking at the interplay of interstitial and in-cloud aerosols in CESM-MAM7. As was detailed in Sect. 1, the interstitial aerosols include both clearsky/dry aerosols and aerosols contained within convective 


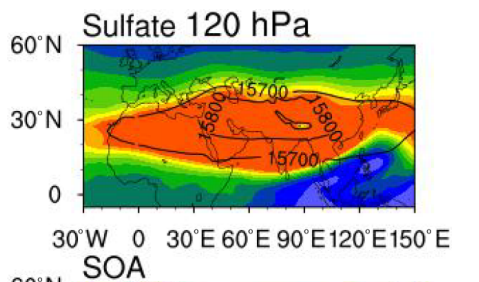

\section{Sulfate $100 \mathrm{hPa}$}

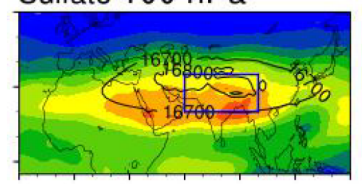

$30^{\circ} \mathrm{W} O 30^{\circ} \mathrm{E} 60^{\circ} \mathrm{E} 90^{\circ} \mathrm{E} 120^{\circ} \mathrm{E} 150^{\circ} \mathrm{E}$ $\mathrm{SOA}$

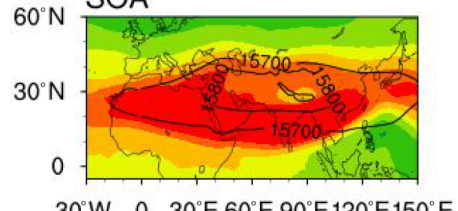

$30^{\circ} \mathrm{W} \quad 0 \quad 30^{\circ} \mathrm{E} 60^{\circ} \mathrm{E} 90^{\circ} \mathrm{E} 120^{\circ} \mathrm{E} 150^{\circ} \mathrm{E}$ $60^{\circ} \mathrm{N}$ POM

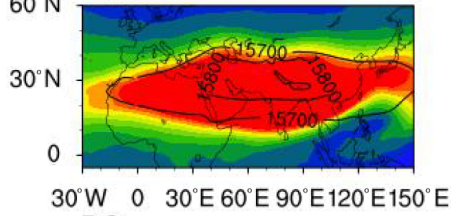
$\mathrm{BC}$
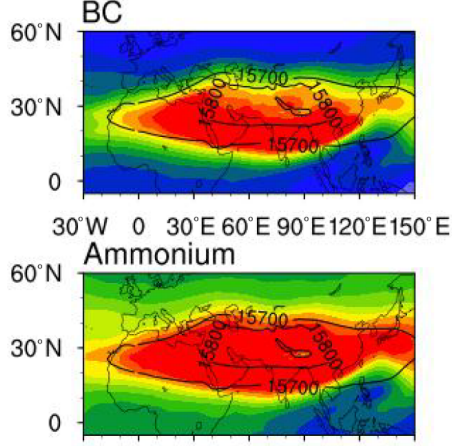

$30^{\circ} \mathrm{W} \quad 0 \quad 30^{\circ} \mathrm{E} 60^{\circ} \mathrm{E} 90^{\circ} \mathrm{E} 120^{\circ} \mathrm{E} 150^{\circ} \mathrm{E}$

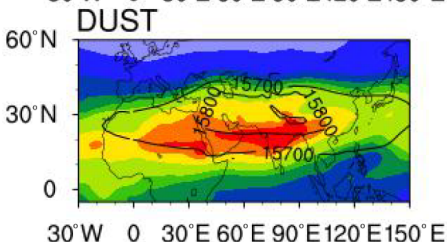

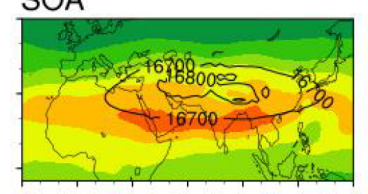

$30^{\circ} \mathrm{W} \quad 0 \quad 30^{\circ} \mathrm{E} 60^{\circ} \mathrm{E} 90^{\circ} \mathrm{E} 120^{\circ} \mathrm{E} 150^{\circ} \mathrm{E}$ POM

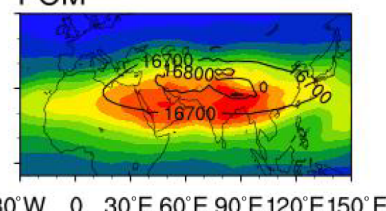

$\mathrm{BC}$

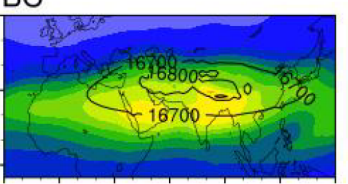
Ammonium

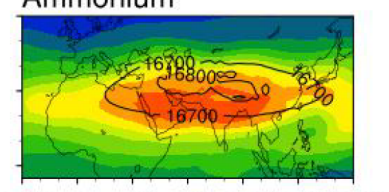

$30^{\circ} \mathrm{W} \quad 0 \quad 30^{\circ} \mathrm{E} 60^{\circ} \mathrm{E} 90^{\circ} \mathrm{E} 120^{\circ} \mathrm{E} 150^{\circ} \mathrm{E}$ DUST

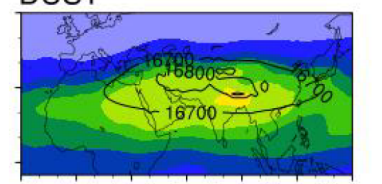

$30^{\circ} \mathrm{W} \quad 0 \quad 30^{\circ} \mathrm{E} 60^{\circ} \mathrm{E} 90^{\circ} \mathrm{E} 120^{\circ} \mathrm{E} 150^{\circ} \mathrm{E}$
Sulfate $80 \mathrm{hPa}$

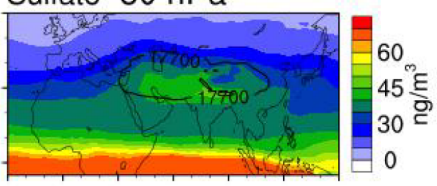

$30^{\circ} \mathrm{W} \quad 0 \quad 30^{\circ} \mathrm{E} 60^{\circ} \mathrm{E} 90^{\circ} \mathrm{E} 120^{\circ} \mathrm{E} 150^{\circ} \mathrm{E}$ SOA

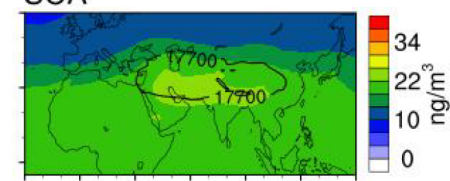

$30^{\circ} \mathrm{W} \quad 0 \quad 30^{\circ} \mathrm{E} 60^{\circ} \mathrm{E} 90^{\circ} \mathrm{E} 120^{\circ} \mathrm{E} 150^{\circ} \mathrm{E}$ POM

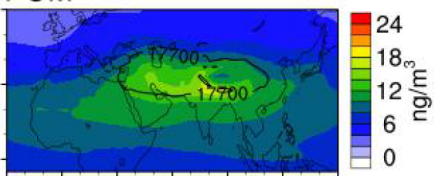

$30^{\circ} \mathrm{W} \quad 0 \quad 30^{\circ} \mathrm{E} 60^{\circ} \mathrm{E} 90^{\circ} \mathrm{E} 120^{\circ} \mathrm{E} 150^{\circ} \mathrm{E}$ $\mathrm{BC}$

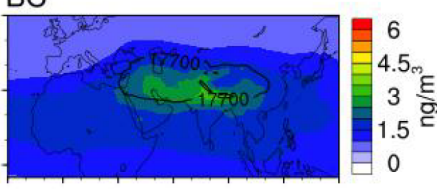

$30^{\circ} \mathrm{W} \quad 0 \quad 30^{\circ} \mathrm{E} 60^{\circ} \mathrm{E} 90^{\circ} \mathrm{E} 120^{\circ} \mathrm{E} 150^{\circ} \mathrm{E}$ Ammonium

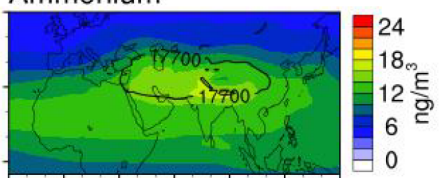

$30^{\circ} \mathrm{W} \quad 0 \quad 30^{\circ} \mathrm{E} 60^{\circ} \mathrm{E} 90^{\circ} \mathrm{E} 120^{\circ} \mathrm{E} 150^{\circ} \mathrm{E}$ DUST

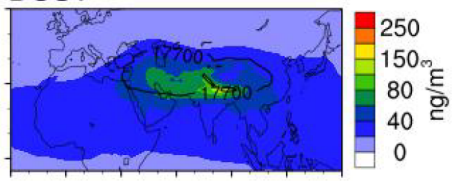

Figure 2. Spatial distribution of the aerosol mass concentration, averaged over July-August 2014, from CESM-MAM7 simulations, for six different aerosol types. From top to bottom row: sulfate, SOA, POM, BC, ammonium (in the accumulation mode) and mineral dust (in the fine dust soil mode). From left to right column: 120, 100 and $80 \mathrm{hPa}$ pressure levels. Note the different color-scale ranges. The black lines in the map represent the geopotential height $>15700 \mathrm{~m}$ at $120 \mathrm{hPa},>16700 \mathrm{~m}$ at $100 \mathrm{hPa}$ and $>17700 \mathrm{~m}$ at $80 \mathrm{hPa}$. The blue box (second panel) represents the area chosen for the subsequent ATAL-specialized analyses $\left(20-35^{\circ} \mathrm{N}, 60-100^{\circ} \mathrm{E}\right)$.

clouds. Our simulations show that during the mature phase of the AMA (July and August), at the same time of increased convection, the AP in convective clouds (maximum of convective outflow at $\sim 250 \mathrm{hPa}$ ) also increase. This causes a maximum of aerosols at lower altitudes. Figure $\mathrm{S} 3$ shows the cloud ice fraction for 2014 averaged for the blue box. In June the fraction of clouds is much smaller than in July and August.

This "double-peak" vertical structure can be found in some observations from recent aircraft and balloon campaigns but is not discussed. For instance, particle-counting observations during the 2015 BATAL campaign (Vernier et al., 2018) have shown two maxima in the aerosol concentration profile, at $\sim 17$ and $\sim 14-15 \mathrm{~km}$ (see Fig. 11 in that paper). They mainly associate the enhanced aerosol concentrations with the influence of convective transport of regional Indian pollutants and the observed lower peak with the presence of ice particles. During the StratoClim campaign carried out in August 2016 and 2017, Brunamonti et al. (2018) observed the frequent presence of ice particles in the AMA, often found embedded within the ATAL. They showed a clear-sky/dry aerosol ATAL signal between 70 and $150 \mathrm{hPa}$ after the application of a cloud filter. As another example of this "double-peak" feature in the vertical ATAL profile, 
Höpfner et al. (2019) observed two peaks for ammonium nitrate aerosols in July 2017 during the StratoClim campaign (see Fig. 4 in this paper). These results support our hypothesis about the simulated lower peak associated with particles in convective clouds or in the convective outflow, although the occurrence of such a lower-peak feature needs confirmation from further in situ observations.

We have also tried to separate the overall in-cloud and purely dry aerosols (these latter ones likely coming from nucleation/condensation processes). In order to analyze the contribution of dry aerosols to the ATAL, we have carried out an analysis to reduce the contribution from convective cloud-borne aerosols. For this purpose, we have filtered out the profiles, in our blue box, for which the extinction coefficient is larger than an arbitrary threshold $\left(1.0 \times 10^{-3} \mathrm{~km}^{-1}\right.$ in our case). Figure S4 shows the evaluation of different filters for the extinction coefficient applied for our box domain for August 2014 (the same behavior is observed for July, not shown). We have applied a filter of $8.0 \times 10^{-4}, 9.0 \times 10^{-4}$, $1.0 \times 10^{-3}$ and $2.0 \times 10^{-3} \mathrm{~km}^{-1}$, respectively, and have evaluated the maximum value obtained at around $100 \mathrm{hPa}$, where our upper peak is located. By varying these threshold values, we arrive at the point of isolating the upper peak, which is satisfactory for $1.0 \times 10^{-3} \mathrm{~km}^{-1}$. Figure $3 \mathrm{~b}, \mathrm{~d}$, $\mathrm{f}$ show the vertical aerosol profiles with the applied filter, from where an isolated upper peak can be seen. This peak, due to the mentioned filtering, is associated with aerosols with limited radiation extinction. Large extinction values are associated with in-cloud aerosols, which are larger in size due to liquid-phase formation, freezing and/or hygroscopic growth (depending on the primary or secondary nature of the aerosols). We then identify as clear-sky/dry AP the ones associated with this upper peak (120-80 hPa). The comparison with AP vertical profiles from Fig. 3a, c, e allows us to point out that in CESMMAM7 both types of aerosols contribute to the ATAL, i.e., clear-sky/dry aerosols and convective cloud-borne aerosols.

It is worth noticing that, for these 2 selected years (2000 and 2014), the aerosol profiles can differ from one aerosol type to another but are quite similar for a given month/year, and a double- or single-peak structure is observed. This variability observed in the ATAL's vertical profiles also reflects the aspect of the dynamical variability of the AMA, which can be put into a relationship with both the long-range transport and convection, as was shown in previous studies (e.g., Qie et al., 2014; Pan et al., 2016; Santee et al., 2017).

\subsection{Trends in aerosol composition of the ATAL}

Figure $4 \mathrm{a}-\mathrm{d}$ show the annual average aerosol total mass concentrations for all the aerosol types simulated by CESMMAM7, in the period 2000-2015, for all modes (Fig. 4a, c) and the isolated accumulation mode (Fig. 4b, d). To account for the whole double-peak phenomenology and to isolate the single dry AP peak (see discussion in Sect. 4.2), the concentrations are averaged between $200-80 \mathrm{hPa}$ (Fig. $4 \mathrm{a}$, b) and
120-80 hPa (Fig. 4c, d). These two vertical ranges allow the differentiation of the ATAL composition based on in-cloud processes or, from another point of view, description of how the composition changes depending on the altitude. No filter has been applied to show the contributions of all aerosols.

The aerosol type that dominates the ATAL, for both altitude ranges, is dust, followed by sulfates and organic particles (secondary and primary). The comparison between Fig. 4a and $\mathrm{c}$ shows that at higher altitudes the amount of sulfates increases slightly and, more markedly, dust amount decreases. Figure 4e shows the percent contribution of aerosols types to the ATAL, between 120 and $80 \mathrm{hPa}$. It is evident that although less dust reaches higher altitudes, this aerosol type is still the mass-dominant aerosol type in the ATAL, contributing around $60 \%$. Even if there still is large disagreement among reported studies about the exact amount of dust present in the ATAL, it is clear that in our study this natural component contributes significantly to the ATAL seasonal build-up due to its transport from the nearby desert regions, like the Taklamakan and Thar deserts, and the northern slope areas of the Tibetan Plateau (Lau et al., 2018; Ma et al., 2019). As was mentioned in Sect. 4.1, the difference in the amount of dust reported by the different authors may be related to the different schemes used for the generation of dust, e.g., how the topography is represented in the model, the resolution of the model and the parameterization of the convection processes.

Wu et al. (2018) evaluated dust emissions in East Asia simulated by 15 climate models participating in the Coupled Model Intercomparison Project Phase 5 (CMIP5) during 1961-2005. They found discrepancies with the observations for all the models, because climate models may not sufficiently represent the trends of surface wind speeds and precipitation. This indicates that there is still a need to improve the representation of the dust cycle in climate models to simulate long-term dust changes.

With the intention of analyzing the composition of the ATAL in terms of anthropogenic and biomass burning emissions, we discuss more in detail the contribution of the nondust aerosols, for which the accumulation mode at two different altitude ranges is shown in Fig. 4b, d. Excluding dust particles, the accumulation mode (a1, size range: 0.056$0.26 \mu \mathrm{m}$ ) is the principal mode that contributes to the ATAL. This can be seen in Fig. S2 in the Supplement. Hence, anthropogenic and biomass burning aerosols that reach the ATAL are principally small and young. The same behavior is observed in the $200-80 \mathrm{hPa}$ range (figure not shown here).

Sulfate aerosols from moderate-to-strong volcanic eruptions, with injection in the UTLS, can also interact with the dynamical features of the AMA (e.g., Sellitto at al., 2017) and, under certain conditions, can impact the ATAL aerosol population. Larger sulfate concentrations in 2009 and 2011 are linked to the volcanic eruptions of Sarychev (June 2009) and Nabro (June 2011). These eruptions injected large quantities of $\mathrm{SO}_{2}$ into the UTLS, just before the onset of the 

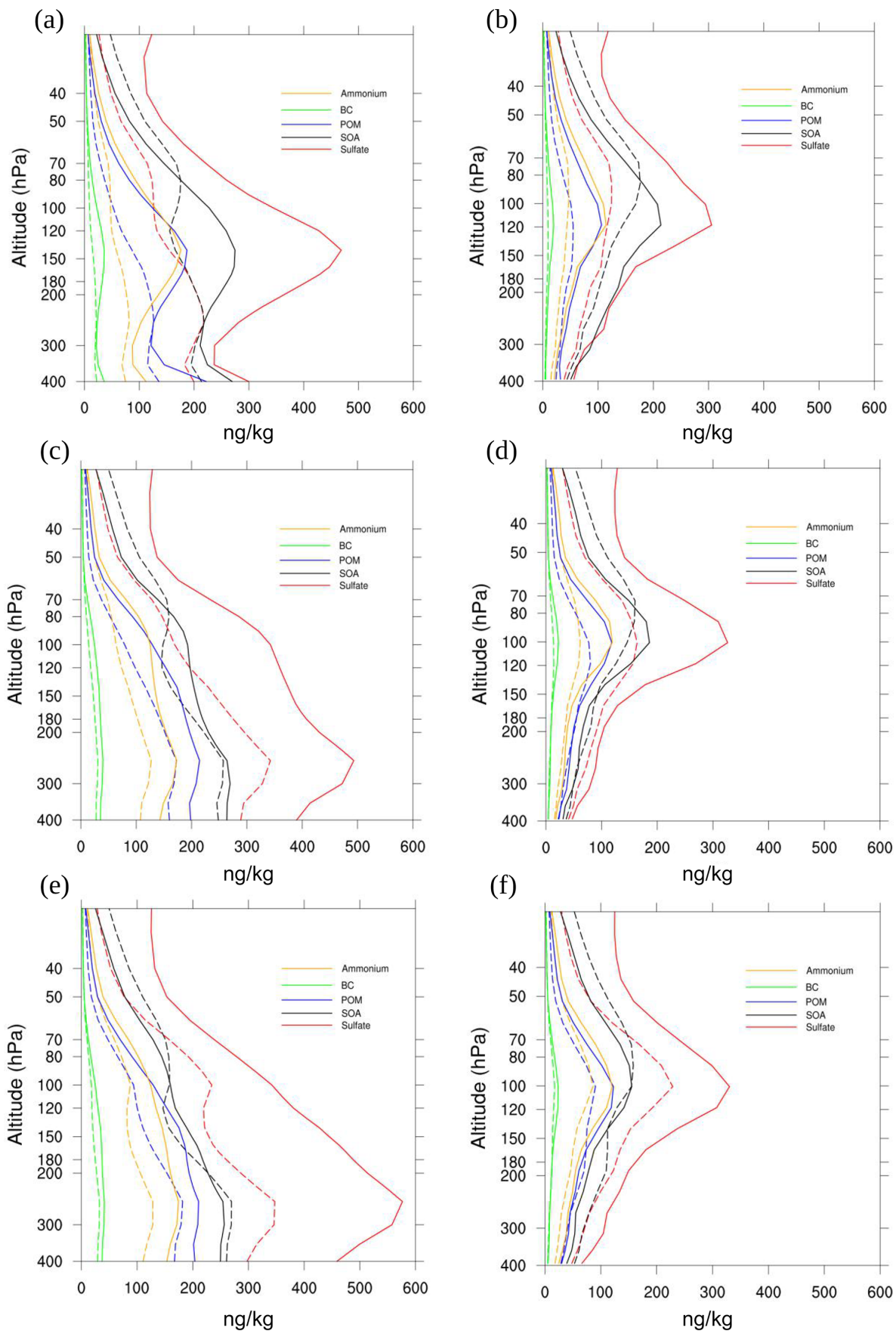

Figure 3. Modeling vertical profiles of aerosol mass concentration of sulfate, SOA, POM, ammonium and BC in the accumulation mode (a1) in $\mathrm{ng} / \mathrm{kg}$ averaged between $20-35^{\circ} \mathrm{N}$ and $60-100^{\circ} \mathrm{E}$; the dashed lines correspond to the year 2000, solid lines the year 2014. (a) Profile for June, (c) July and (e) August. (b), (d), (f): same as (a), (c) and (e) but with the extinction filter applied $\left(>1.0 \times 10^{-3} \mathrm{~km}^{-1}\right)$ to reduce the contribution of convective cloud-borne aerosols.

AMA. The subsequently formed volcanic sulfates from $\mathrm{SO}_{2}$ conversion to particles increased the background inside and outside the AMA and therefore contributed to the ATAL burden during these 2 years. For these years influenced by moderate volcanic eruptions, the concentration of sulfate in- creases drastically and reaches or even exceeds the dust concentration (see Fig. 4).

Excluding dust and focusing on the mostly anthropogenic accumulation mode, Fig. $4 \mathrm{f}$ suggests that the fraction of the ATAL of anthropogenic origin is composed of about $40 \%$ sulfate, $30 \%$ SOA, $15 \%$ POM, $14 \%$ ammonium and less 
(a)
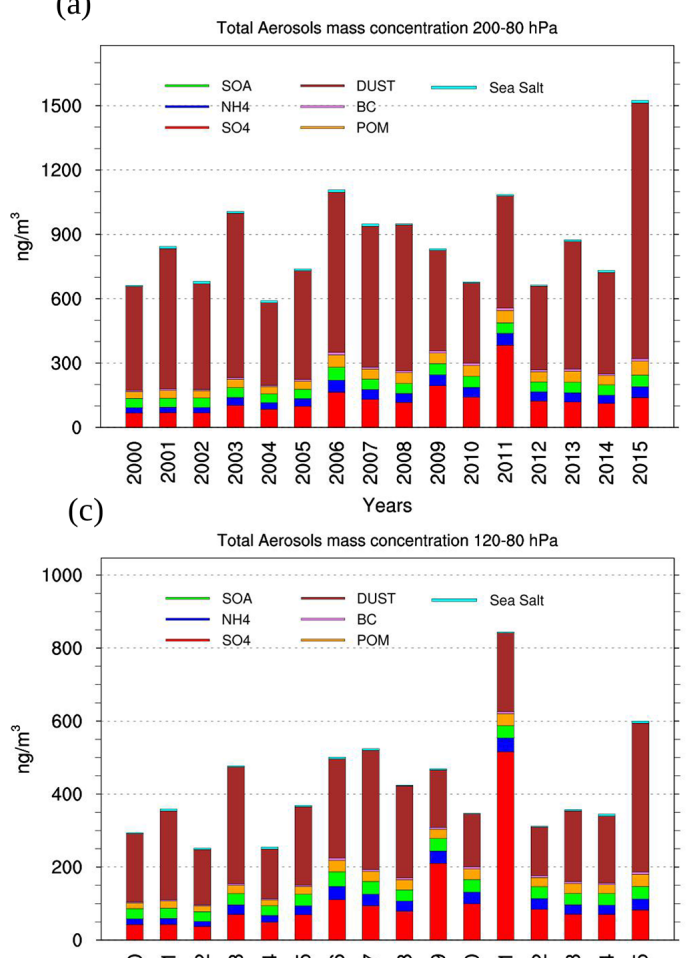

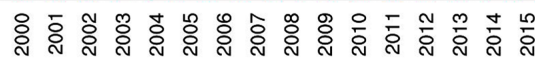

(e)

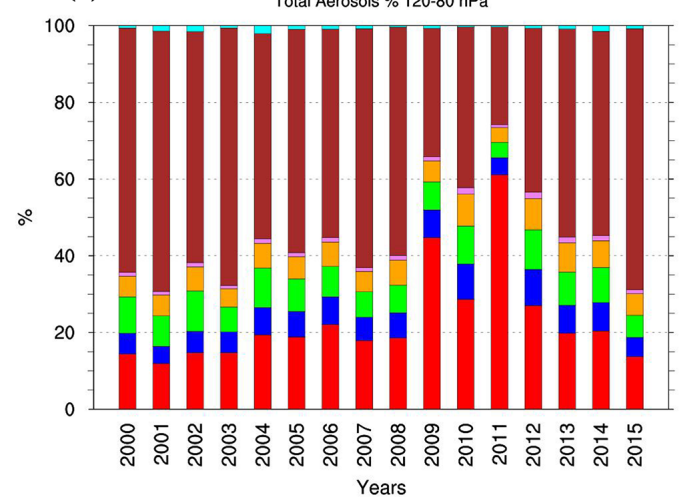

(b)

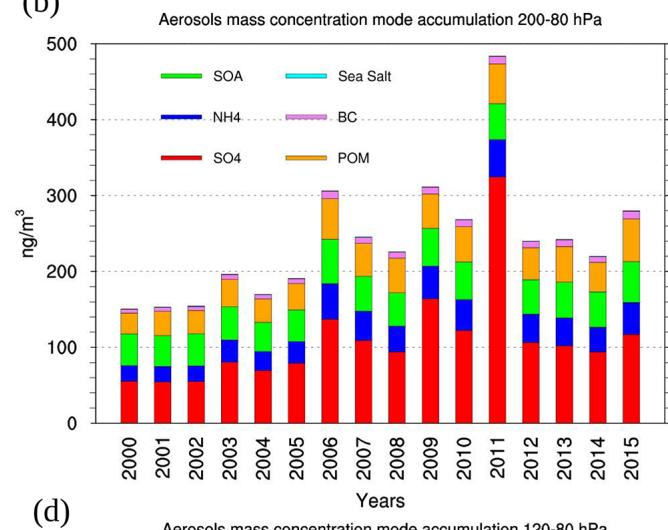

(d)

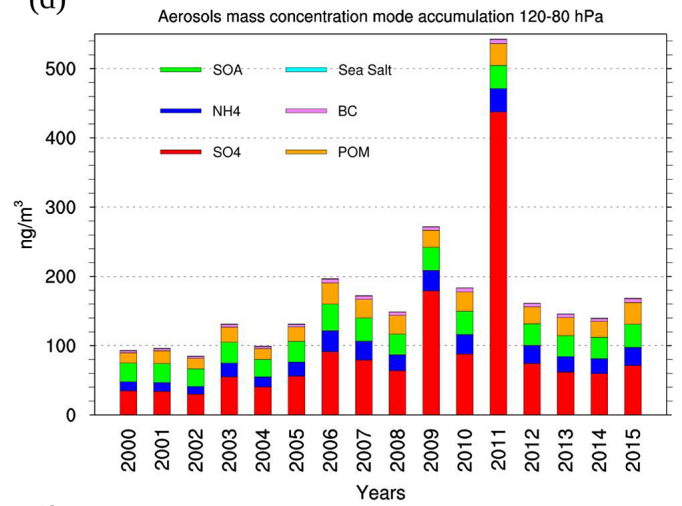

(f)

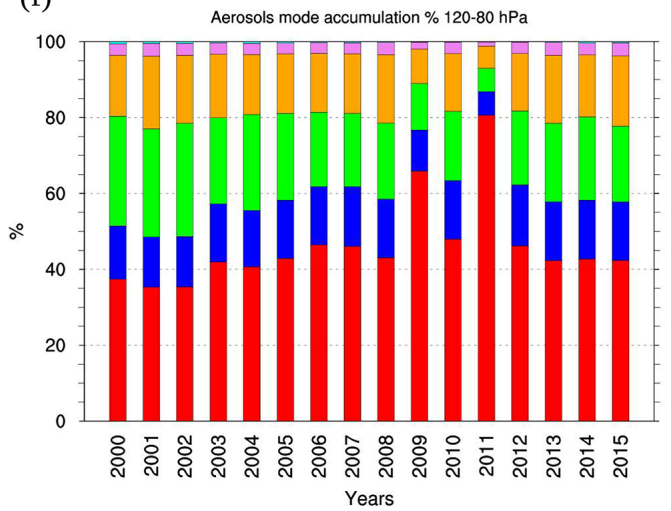

Figure 4. Evolution of the total aerosol mass concentration of all the aerosol types present in CESM-MAM7 in all the modes averaged at 20-35 $\mathrm{N}, 60-100^{\circ} \mathrm{E}$ for July-August, (a) between 200 and $80 \mathrm{hPa}$, (c) between 120 and $80 \mathrm{hPa}$, and (e) percent amount at $120-80 \mathrm{hPa}$. (b), (d) and (f) are the same as (a), (c) and (e) but only for the aerosols in the accumulation mode.

than $3 \%$ BC. Compared to the results reported by $\mathrm{Yu}$ et al. (2015), our results show about the same percentage of sulfate in the ATAL but less organics, i.e., $45 \%$ aggregating SOA and POM for our study compared with $60 \%$ of organics as reported by Yu et al. (2015).

In the following, we evaluate the decadal trends of the different aerosol types in the ATAL. In particular, we have estimated the trends for the dust in the fine soil dust mode (Fig. 5a) and all other aerosol types in the accumulation mode (Fig. 5b, c). The concentrations for each year are averaged between 120 and $80 \mathrm{hPa}$ pressure levels and over the domain defined by the blue box of Fig. 2, excluding the years with volcanic eruptions impacting the UTLS, i.e., 2005-2009 and 2011-2012 (Manam: April 2005; Soufrière Hills: August 2006; Tavurvur: October 2006; Okmok: August 2008; Kasatochi: August 2008; Sarychev: June 2009; Nabro: June 2011, taken from Khaykin et al., 2017; see Table 3 in their paper).

As can been seen from Fig. 5a, dust does not display any clear trend. The $p$ value (a $p$ value less than 0.05 confirms that a statistical test is significant in indicating strong evidence against the null hypothesis) of 0.64 confirms an in- 
significant positive value (the same behavior is observed in the $200-80 \mathrm{hPa}$ range, figure not shown here), reinforcing the evidence that the variation in dust concentration in the ATAL region is only subject to the natural interannual variability, as pointed out in Yuan et al. (2019), with no specific longterm trends. The sparse variations of dust in the ATAL reflect the influence of other factors not related to the ASM, like the variability of extratropical westerlies that can strongly affect the long-range dust transport at high elevations or the wet scavenging in and below clouds that can overcome the effect of lofting by deep convection.

Figure 5b, c show the trends for all the aerosols in the accumulation mode averaged in our box over the $120-80 \mathrm{hPa}$ vertical level range, respectively, without and with the extinction filter applied so as to isolate dry from in-cloud (including from convective clouds) aerosols. All the aerosol types show an increase over the simulated 16 years. This mirrors the increase in the emissions in Asia. From Fig. 5b, it can be seen that sulfate aerosol trends in the ATAL roughly double their concentration from $\sim 36 \mathrm{ng} \mathrm{m}^{-3}$ in 2000 to $\sim 75 \mathrm{ng} \mathrm{m}^{-3}$ in 2015 (i.e., about $108 \%$ increase in 15 years). Marked increases are also observed for POM $(\sim 80 \%)$, ammonium $(\sim 100 \%)$ and $\mathrm{BC}(\sim 93 \%)$, while for SOA the trend is weaker, i.e., going from $\sim 27$ to $33 \mathrm{ng} \mathrm{m}^{-3}(\sim 24 \%)$. The concentrations for the years 2000 and 2015 , the percentage of increment for the 15 modeled years, the $R$ coefficient for the trends and the $p$ value are summarized in Table 2 .

Figure $5 \mathrm{c}$ shows the trends of dry aerosols, i.e., with the extinction filter applied, in the ATAL between 120 and $80 \mathrm{hPa}$. The comparison between Fig. 5c with b, together with the values reported in Table 2, shows that the increasing trends and correlation values are slightly smaller than values reported without applying the filter. This reflects the fact that at $120-80 \mathrm{hPa}$ the dry aerosols contribute a larger fraction of the ATAL than convective cloud-borne aerosols.

The analysis of differences without and with the application of the extinction filter (i.e., (dry + convective)-(dry) aerosols) reveals that the increase for convective cloudborne aerosols between 120 and $80 \mathrm{hPa}$ in our box domain is $\sim 22 \%$ for sulfate, $\sim 10 \%$ for SOA, $\sim 28 \%$ for POM, $\sim 20 \%$ for $\mathrm{NH}_{4}$ and $\sim 25 \%$ for $\mathrm{BC}$ (values derived from Table 2).

We have also carried out the same analysis for the larger altitude interval of the ATAL, i.e., between 200 and $80 \mathrm{hPa}$ (Fig. 5d and e). More convective cloud-borne aerosols are present in this case. Thus, the differences for the cases without versus with the extinction filter (calculated from Table 2) are larger than the previous case $(\sim 36 \%$ for sulfates, $\sim 44 \%$ for POM, $\sim 32 \%$ for $\mathrm{NH}_{4}, 47 \%$ for $\mathrm{BC}$ and $\sim 21 \%$ for SOA).

\subsection{Aerosol optical depth (AOD) of the ATAL}

Figure $6 \mathrm{a}$ and $\mathrm{b}$ show the aerosol optical depth (AOD) at $550 \mathrm{~nm}$ averaged for July-August and between 20 and $35^{\circ} \mathrm{N}$ latitude, for selected years between 2000 and 2015, as a function of the longitude. As done before, two different altitude ranges, $200-80 \mathrm{hPa}$ (Fig. 6a) and $120-80 \mathrm{hPa}$ (Fig. 6b), are analyzed, to account for the double-peak ATAL introduced in Sect. 4.2. The AOD is calculated from the total aerosol extinction provided by CESM-MAM7. Then, in the AOD the extinction of all the aerosols from all modes and both dry aerosols and convective in-cloud aerosols are taken into account in the AOD. For the full double-peak ATAL (20$80 \mathrm{hPa}$ ), AOD values from about 0.007 , in 2000 , to about 0.016 , in 2015, are obtained in the core of the AMA region (Fig. 6a). These values are about a factor 2-3 larger than the values reported by Vernier et al. (2015) using SAGEII and CALIOP satellite data. The values reported by Vernier et al. (2015) include a cloud-screening procedure to attempt to remove cirrus clouds. One can argue that this filter might have screened out some aerosols with high extinction, like those we identify from convective cloud-borne aerosols in our lower peak. Vernier et al. (2015) also used a depolarization filter which might have removed irregularly shaped particles, with a possible impact on dust. This possibility has been suggested by Yu et al. (2015), who also reported an AOD simulated by the CESM1/CARMA model with a factor of $\sim 2$ larger than Vernier et al. (2015). The maxima observed in Fig. 6a are comparable with those of Yu et al. (2015) despite the fact that we have used a different latitudinal extent ( 20 to $35^{\circ} \mathrm{N}$ ) to study the ATAL.

AOD values from about 0.0019 , in 2000 , to about 0.004 , in 2015, are found over the $120-80 \mathrm{hPa}$ range where dry aerosols dominate (Fig. 6b). Between 200 and $80 \mathrm{hPa}$, higher AOD values are obtained as a result of a large contribution of convective cloud-borne aerosols at this altitude range. The difference between the AOD values obtained for the two altitude ranges in Fig. 6a and $b$ points to the importance of what we have identified as convective in-cloud aerosols.

Figure $6 \mathrm{c}$ and $\mathrm{d}$ show the temporal evolution of the yearly ATAL AOD from 2000 to 2015 for our selected box (20$35^{\circ} \mathrm{N}, 60-100^{\circ} \mathrm{E}$ ), for the $200-80 \mathrm{hPa}$ (Fig. 6a) and 120 $80 \mathrm{hPa}$ (Fig. 6d) vertical ranges. Our simulated trend is comparable to that observed by Vernier et al. (2015) with an increase by a factor $\sim 1.5-2.0$ over the period, although AOD trend values are very difficult to compare between both works due to different considered periods and different cloud-filtering procedures. Figure $6 \mathrm{c}$ and d show that accounting for the double-ATAL-peak structure leads to different AOD trend values and reflects the importance of the altitude range used to estimate the year-to-year variability.

The attribution of the possible causes to the increase in the aerosol content and optical depth in the ATAL between 2000 and 2015 (e.g., increase in Asian emissions, more efficient vertical transport or different chemical/microphysical processes) requires further investigations and the continuous monitoring of ATAL burden and properties in the future. 
(a)
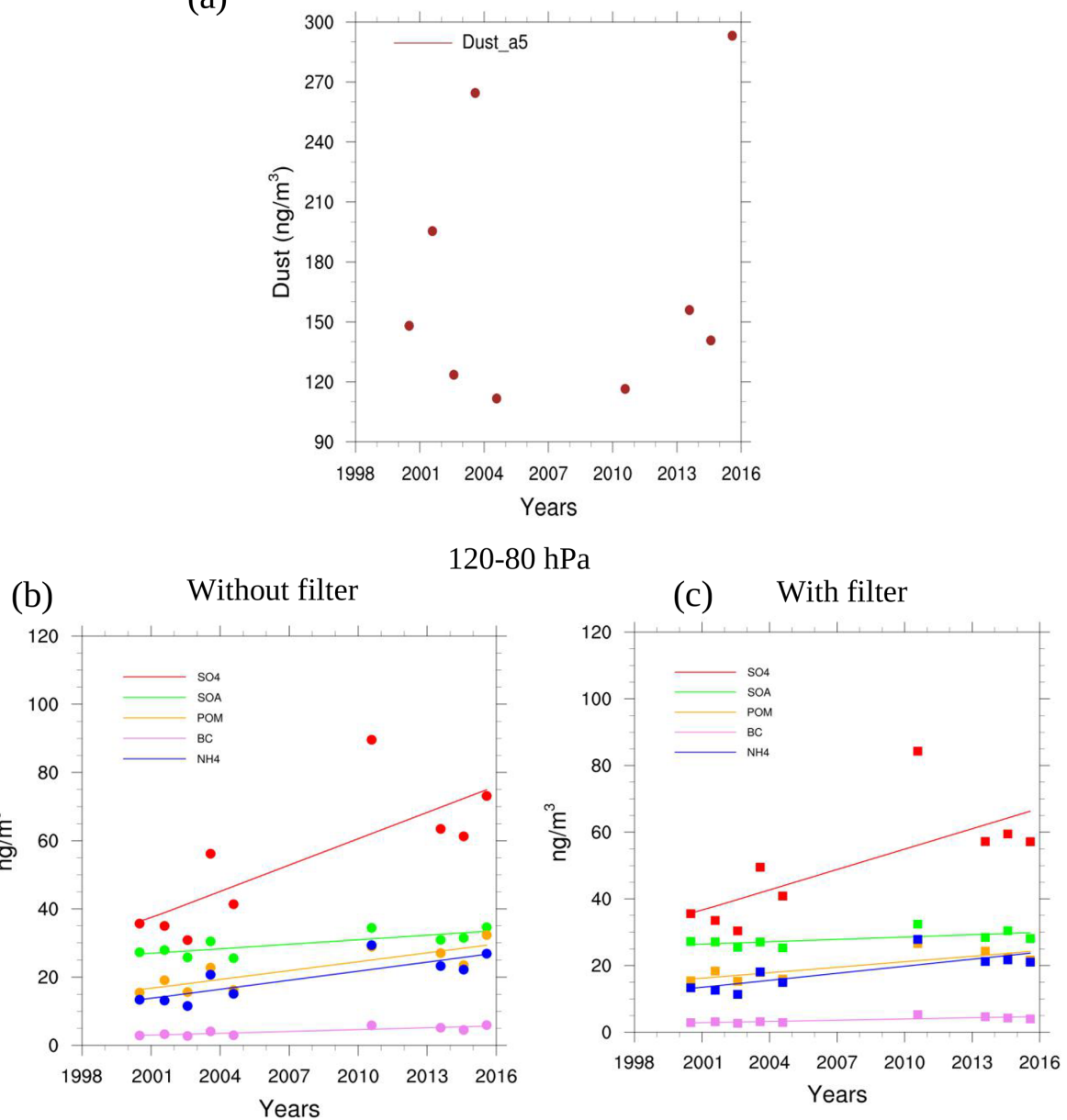

(d)

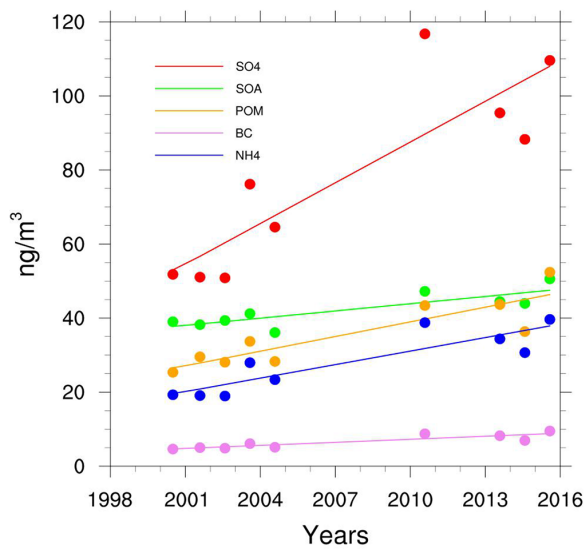

(e) With filter

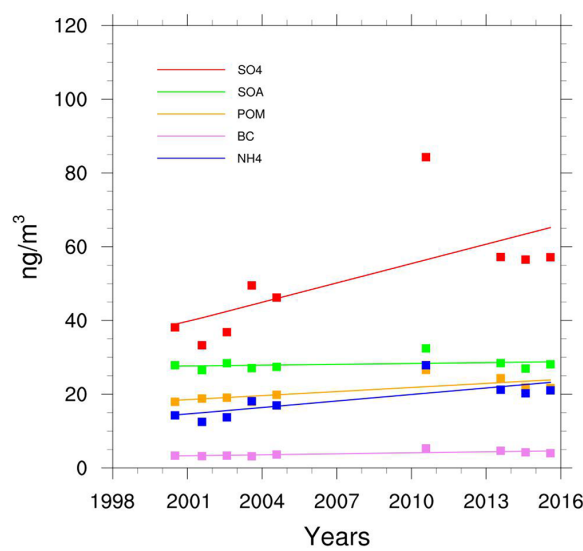

Figure 5. Aerosol mass concentration trends simulated by CESM-MAM7 averaged between $20-35^{\circ} \mathrm{N}$ and $60-100^{\circ} \mathrm{E}$ for July and August.

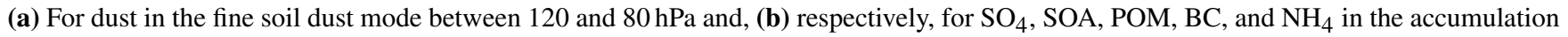
mode between 120 and $80 \mathrm{hPa}$. (c) Same as (b) but with the extinction filter applied. (d) and (e): same as (b) and (c) but averaged between 200 and $80 \mathrm{hPa}$. The plots show the trends excluding the years with volcanic eruptions impacting the UTLS. 
Table 2. Averaged aerosol mass concentration and percentage of the increase from 2000 to 2015 for $\mathrm{SO}_{4}, \mathrm{SOA}, \mathrm{POM} \mathrm{NH}_{4}$ and $\mathrm{BC}$, averaged for the summer period July-August at $20-35^{\circ} \mathrm{N}, 60-100^{\circ}$ E between $120-80 \mathrm{hPa}$ and $200-80 \mathrm{hPa}$, without and with the extinction filter applied. The $R$ coefficient from Fig. $5 \mathrm{~b}$ to e and the respective $p$ value are also reported.

\begin{tabular}{|c|c|c|c|c|c|c|c|c|c|c|c|}
\hline Aerosol & $\mathrm{SO}_{4}$ & SOA & POM & $\mathrm{NH}_{4}$ & $\mathrm{BC}$ & Dust & $\mathrm{SO}_{4}$ & SOA & POM & $\mathrm{NH}_{4}$ & $\mathrm{BC}$ \\
\hline $120-80 \mathrm{hPa}$ & \multicolumn{6}{|c|}{ Without filter } & \multicolumn{5}{|c|}{ Filter extinction $1 \times 10^{-3} \mathrm{~km}^{-1}$} \\
\hline $2000\left(\mathrm{ng} \mathrm{m}^{-3}\right)$ & 36 & 26.8 & 16.4 & 13.4 & 2.9 & 159 & 35.7 & 26.3 & 16 & 13.2 & 2.8 \\
\hline $2015\left(\mathrm{ng} \mathrm{m}^{-3}\right)$ & 75 & 33.4 & 29.4 & 26.7 & 5.6 & 188 & 66.3 & 30 & 24.2 & 23.7 & 4.7 \\
\hline$\%$ increment & 108.3 & 24.6 & 79.3 & 99.2 & 93.1 & 18.2 & 85.7 & 14 & 51.2 & 79.5 & 68 \\
\hline$R$ coefficient & 0.78 & 0.79 & 0.85 & 0.83 & 0.86 & 0.18 & 0.72 & 0.63 & 0.80 & 0.79 & 0.80 \\
\hline$p$ value & 0.010 & 0.010 & 0.003 & 0.005 & 0.002 & 0.64 & 0.02 & 0.07 & 0.007 & 0.01 & 0.008 \\
\hline $200-80 \mathrm{hPa}$ & \multicolumn{6}{|c|}{ Without filter } & \multicolumn{5}{|c|}{ Filter extinction $1 \times 10^{-3} \mathrm{~km}^{-1}$} \\
\hline $2000\left(\mathrm{ng} \mathrm{m}^{-3}\right)$ & 53 & 37.7 & 26.5 & 19.6 & 4.7 & & 39 & 27.6 & 18.3 & 14.4 & 3.2 \\
\hline $2015\left(\mathrm{ng} \mathrm{m}^{-3}\right)$ & 108 & 47.5 & 46.3 & 37.9 & 9 & & 65.2 & 28.8 & 23.9 & 23.2 & 4.6 \\
\hline$\%$ increment & 103.8 & 26 & 75 & 93.4 & 91.5 & & 67 & 4.3 & 30.6 & 61 & 44 \\
\hline$R$ coefficient & 0.87 & 0.84 & 0.88 & 0.88 & 0.89 & & 0.70 & 0.27 & 0.74 & 0.74 & 0.74 \\
\hline$p$ value & 0.002 & 0.003 & 0.001 & 0.001 & 0.0008 & & 0.04 & 0.48 & 0.02 & 0.02 & 0.02 \\
\hline
\end{tabular}

(a)
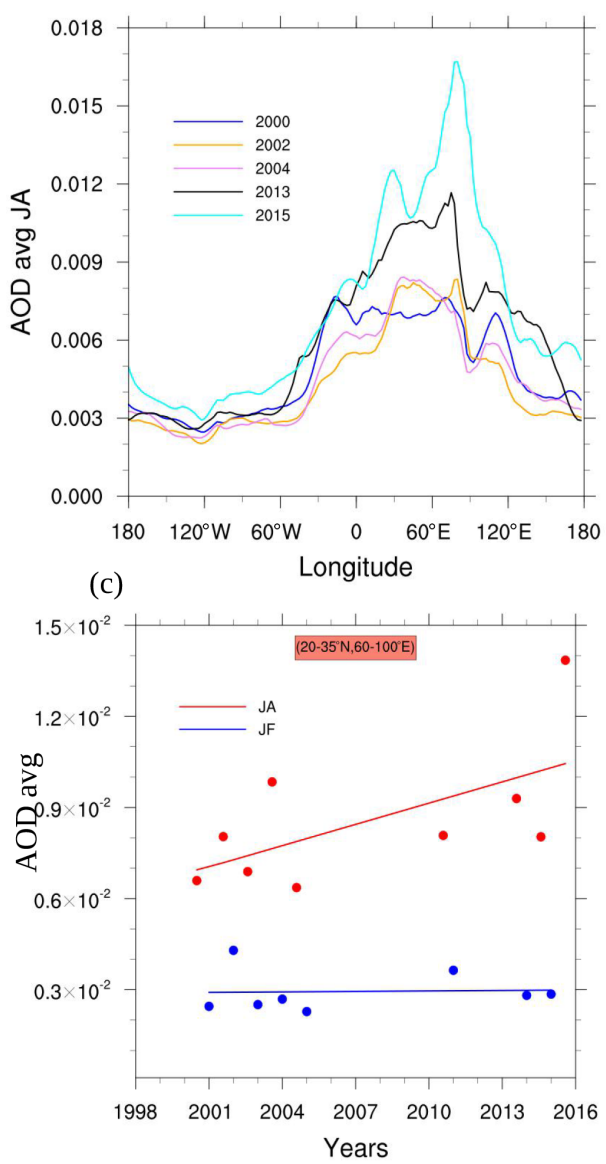

(b)
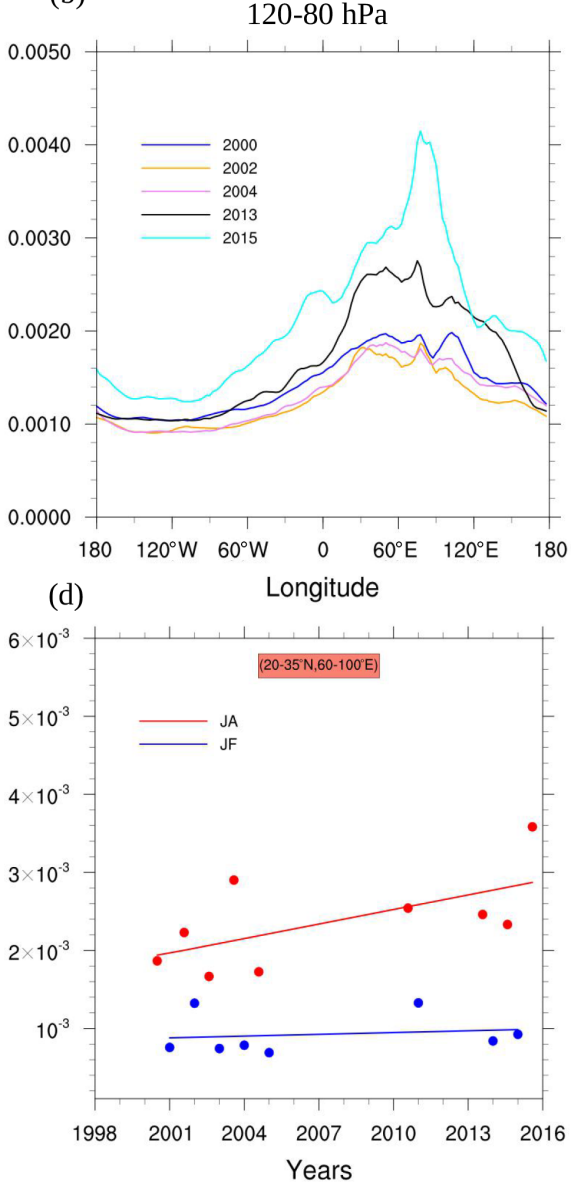

Figure 6. (a, b) AOD at $550 \mathrm{~nm}$ averaged from 20 to $35^{\circ} \mathrm{N}$ of latitude for July-August, (a) between 200 and $80 \mathrm{hPa}$ (around 13 to $18 \mathrm{~km}$ ), and (b) between 120 and $80 \mathrm{hPa}$ (around 15.7 to $18 \mathrm{~km}$ ). Different colors represent the different selected years. (c, d) AOD trends for JulyAugust (red) and January-February (blue) averaged between $20-35^{\circ} \mathrm{N}$ and $60-100^{\circ} \mathrm{E}$, (c) between 200 and $80 \mathrm{hPa}$ and (d) between 120 and $80 \mathrm{hPa}$. The plots show the trends excluding the years with volcanic eruptions impacting the UTLS. 


\section{Conclusions}

In this paper, we have presented the results for our longterm simulation, i.e., 16 years (15 January 2000-15 December 2015), to investigate the composition and trends of the specific ATAL aerosols using the CESM-MAM7 model. The model was driven by the CMIP6 emission inventory for the anthropogenic and biomass burning emissions of the principal trace gases and aerosols, while the biogenic emissions were taken from the MEGAN-MACC inventory. During summer, a confinement of polluted air masses has been found within the AMA region, which is tied to the ATAL position. The model results show overall good agreement with the space-time behavior of CO in the UTLS region observed by the MLS and ACE-FTS space-borne instruments, despite a possible underestimation in the $\mathrm{CO}$ burden due to the underestimation of surface emissions. In particular, the horizontal distribution of modeled $\mathrm{CO}$ is in good agreement with MLS data, and the vertical structure in the AMA shows a maximum near $150 \mathrm{hPa}$ in agreement with the available ACE-FTS observations.

Our model results indicate that dust is a dominating aerosol type in terms of mass in the ATAL, in agreement with other studies (e.g., Lau et al., 2018; Ma et al., 2019). However, the lack of in situ or satellite measurements of dust in the AMA region makes the validation of this result difficult. Our modeled burdens of dust in the ATAL are larger than what has been reported in the past (e.g., Fadnavis et al., 2013; Yu et al., 2015; Fairlie et al., 2020). The higher amount of dust found in our model could be due to excessive convective transport, a lack of secondary activation of aerosols entrained into convective updrafts, a too strong dust transport in the upper troposphere from Africa and the Middle East (Wu et al., 2019), as well as the sensitivity of dust emissions to the resolution of the model (Brühl et al., 2018; Wu et al., 2019).

The differences between the simulated dust burdens between different models can be linked to the different physical processes computed for dust emissions (e.g., wind speed, hydrological parameters and soil properties).

Apart from dust, the average partitioning for other aerosol types contained in the ATAL (from anthropogenic and biomass burning emissions) is the following: $40 \%$ sulfate, $30 \%$ secondary organic aerosols, $15 \%$ primary organic matter, $14 \%$ ammonium and less than $3 \%$ black carbon. Nitrate aerosols are expected to be an important aerosol component in Asia (e.g., Höpfner et al., 2019) due to the increase in nitrogen oxides and ammonia emissions but are not simulated in our work.

For non-dust aerosols the accumulation mode dominates the anthropogenic and biomass burning ATAL aerosols. A marked positive trend of anthropogenic and biomass burning aerosol concentrations is found, with up to a factor of 2 increase in mass concentrations between 2000 and 2015. It is important to note that the simulated aerosol trends depend on the emission inventory used. For example, Zheng et al. (2018) showed that after 2013 the $\mathrm{SO}_{2}$ Chinese emissions have decreased due to the implementation of desulfurization systems in power plants. However, this recent inventory is not included in the CEDS emission inventory used in this work, and this could have some different implications in the trends we have calculated.

Our simulations reveal a double-peak structure in the vertical profile of aerosols of the ATAL, highlighting the contribution of two types of aerosols, i.e., "cloud-borne" aerosols, including those from convective clouds and "clear-sky/dry" aerosols. The CESM-MAM7 simulations have allowed us to analyze separately the contributions of these two types of aerosols. Dry aerosols contribute to the higher peak (peaking around $80-120 \mathrm{hPa}$ ) and convective cloud-borne aerosol to the lower peak (peaking around 200-250 hPa). We show that the contribution of the convective cloud-borne aerosols to the ATAL generally increases during the phases of the mature and late ATAL, in July-August, shifting the maximum of aerosol concentrations to lower altitudes. The dry aerosols are generally dominating in the early phases of the ATAL. This "double-peak" vertical structure has been observed in recent balloon and aircraft campaigns (e.g., Vernier et al., 2018; Höpfner et al., 2019) but has not been discussed in detail so far. These observations support our simulation results, which in turn provide a possible explanation for the observations. Given the uncertainties discussed throughout the paper, the ability of our simulations to represent the reality of the convective transport in the ASM is not entirely clear, but the model results provide hypotheses for follow-up studies.

The obtained AOD values show an enhancement by a factor $\sim 1.5-2.0$ between the $200-80$ and $120-80 \mathrm{hPa}$ levels. Relatively large AOD values are observed for the $200-80 \mathrm{hPa}$ layer, increasing from 0.007 in 2000 to 0.016 in 2015. These large values mirror the fact that extinction coefficients take into account the complete double-peak ATAL, including both dry and convective cloud-borne aerosols.

Code availability. The release version 1.2.2 of CESM can be downloaded from http://www.cesm.ucar.edu/models/cesm1.2/tags/index. html\#CESM1_2_2 (NCAR, 2014).

Data availability. Atmospheric Forcing data, regridded from the Modern-Era Retrospective analysis for Research and Applications, Version 2 (MERRA2) data and prepared as meteorological variables to run CESM and WRF simulations are available at https://rda.ucar.edu/datasets/ds313.3/ (NCAR/UCAR and Climate and Global Dynamics Division, 2020), CMIP6 emissions files are available at https://svn-ccsm-inputdata.cgd.ucar.edu/trunk/inputdata/atm/ cam/chem/emis/CMIP6_emissions_1750_2015/ (Lamarque and Emmons, 2020), ACE-FTS at https://doi.org/10.20383/101.0291 (Bernath et al., 2020) and MLS data at https://mls.jpl.nasa.gov/data/ (Livesey et al., 2020). 
Supplement. The supplement related to this article is available online at: https://doi.org/10.5194/acp-21-2745-2021-supplement.

Author contributions. AB, PS, GB and FJ designed the research and the analysis and interpretation of the model results. AB performed the model simulation with the support of FJ. CK performed the satellite analysis from MLS and ACE-FTS data. BL was involved in the discussion and results interpretation. $\mathrm{AB}$ prepared the manuscript with contributions and discussions from all the coauthors.

Competing interests. The authors declare that they have no conflict of interest.

Special issue statement. This article is part of the special issue "StratoClim stratospheric and upper tropospheric processes for better climate predictions (ACP/AMT inter-journal SI)". It is not associated with a conference.

Acknowledgements. The authors wish to thank the CaSciModOT structure (Calcul Scientifique et Modélisation Orléans-Tours), part of the French national network of complex systems (RNSC Réseau National des Systèmes Complexes), thanks to which the simulations could be completed.

Adriana Bossolasco would also like to thank the NCAR/CESM online discussion board for many helpful technical discussions that helped throughout this study, and thanks especially to Louisa Emmons and Simone Tilmes.

Furthermore, the authors thank the ACE-FTS and MLS teams.

Financial support. This research has been supported by the Agence Nationale de La Recherche (grant no. ANR-17-CE01-0015, TTLXing), the VOLTAIRE project (ANR-10-LABX-100-01) funded by ANR through the PIA (Programme d'Investissement d'Avenir), and the Deutsche Forschungsgemeinschaft (DFG, German Research Foundation, grant no. 409585735).

Review statement. This paper was edited by Gabriele Stiller and reviewed by three anonymous referees.

\section{References}

Abdul-Razzak, H. and Ghan, S. J.: A parameterization of aerosol activation: 2. Multiple aerosol types, J. Geophys. Res.-Atmos., 105, 6837-6844, https://doi.org/10.1029/1999JD901161, 2000.

Barret, B., Sauvage, B., Bennouna, Y., and Le Flochmoen, E.: Upper-tropospheric $\mathrm{CO}$ and $\mathrm{O} 3$ budget during the Asian summer monsoon, Atmos. Chem. Phys., 16, 9129-9147, https://doi.org/10.5194/acp-16-9129-2016, 2016.
Basha, G., Ratnam, M. V., and Kishore, P.: Asian summer monsoon anticyclone: trends and variability, Atmos. Chem. Phys., 20, 6789-6801, https://doi.org/10.5194/acp-20-6789-2020, 2020.

Bergman, J. W., Fierli, F., Jensen, E. J., Honomichl, S., and Pan, L. L.: Boundary layer sources for the Asian anticyclone: Regional contributions to a vertical conduit, J. Geophys. Res.-Atmos., 118, 2560-2575, https://doi.org/10.1002/jgrd.50142, 2013.

Bergman, J. W., Fierli, F., Jensen, E. J., Honomichl, S., and Pan, L. L.: Boundary layer sources for the Asian anticyclone: Regional contributions to a vertical conduit, J. Geophys. Res.-Atmos., 118, 2560-2575, https://doi.org/10.1002/jgrd.50142, 2013.

Bernath, P. F., McElroy, C. T., Abrams, M. C., Boone, C. D., Butler, M., Camy-Peyret, C., Carleer, M., Clerbaux, C., Coheur, P.-F., Colin, R., DeCola, P., DeMazière, M., Drummond, J. R., Dufour, D., Evans, W. F. J., Fast, H., Fussen, D., Gilbert, K., Jennings, D. E., Llewellyn, E. J., Lowe, R. P., Mahieu, E., McConnell, J. C., McHugh, M., McLeod, S. D., Michaud, R., Midwinter, C., Nassar, R., Nichitiu, F., Nowlan, C., Rinsland, C. P., Rochon, Y. J., Rowlands, N., Semeniuk, K., Simon, P., Skelton, R., Sloan, J. J., Soucy, M.-A., Strong, K., Tremblay, P., Turnbull, D., Walker, K. A., Walkty, I., Wardle, D. A., Wehrle, V., Zander, R., and Zou, J.: Atmospheric Chemistry Experiment (ACE): Mission overview, Geophys. Res. Lett., 32, L15S01, https://doi.org/10.1029/2005GL022386, 2005.

Bernath, P. F., Steffen, J., Crouse, J., and Boone, C. D.: Atmospheric Chemistry Experiment SciSat Level 2 Processed Data, v4.0, Federated Research Data Repository, https://doi.org/10.20383/101.0291, 2020.

Bian, J., Pan, L. L., Paulik, L., Vömel, H., Chen, H., and Lu, D.: In situ water vapor and ozone measurements in Lhasa and Kunming during the Asian summer monsoon, Geophys. Res. Lett., 39, L19808, https://doi.org/10.1029/2012GL052996, 2012.

Bian, J., Li, D., Bai, Z., Li, Q., Lyu, D., and Zhou, X.: Transport of Asian surface pollutants to the global stratosphere from the Tibetan Plateau region during the Asian summer monsoon, Natl. Sci. Rev., 7, 516-533, https://doi.org/10.1093/nsr/nwaa005, 2020.

Brunamonti, S., Jorge, T., Oelsner, P., Hanumanthu, S., Singh, B. B., Kumar, K. R., Sonbawne, S., Meier, S., Singh, D., Wienhold, F. G., Luo, B. P., Boettcher, M., Poltera, Y., Jauhiainen, H., Kayastha, R., Karmacharya, J., Dirksen, R., Naja, M., Rex, M., Fadnavis, S., and Peter, T.: Balloon-borne measurements of temperature, water vapor, ozone and aerosol backscatter on the southern slopes of the Himalayas during StratoClim 2016-2017, Atmos. Chem. Phys., 18, 15937-15957, https://doi.org/10.5194/acp-18-15937-2018, 2018.

Brühl, C., Schallock, J., Klingmüller, K., Robert, C., Bingen, C., Clarisse, L., Heckel, A., North, P., and Rieger, L.: Stratospheric aerosol radiative forcing simulated by the chemistry climate model EMAC using Aerosol CCI satellite data, Atmos. Chem. Phys., 18, 12845-12857, https://doi.org/10.5194/acp-18-128452018, 2018.

Dethof, A., O'Neill, A., Slingo, J. M., and Smit, H. G. J.: A mechanism for moistening the lower stratosphere involving the Asian summer monsoon, Q. J. R. Meteorol. Soc., 125, 1079-1106, https://doi.org/10.1002/qj.1999.49712555602, 1999.

Fadnavis, S., Semeniuk, K., Pozzoli, L., Schultz, M. G., Ghude, S. D., Das, S., and Kakatkar, R.: Transport of aerosols into the UTLS and their impact on the Asian monsoon region as seen in 
a global model simulation, Atmos. Chem. Phys., 13, 8771-8786, https://doi.org/10.5194/acp-13-8771-2013, 2013.

Fadnavis, S., Kalita, G., Kumar, K. R., Gasparini, B., and Li, J.-L. F.: Potential impact of carbonaceous aerosol on the upper troposphere and lower stratosphere (UTLS) and precipitation during Asian summer monsoon in a global model simulation, Atmos. Chem. Phys., 17, 11637-11654, https://doi.org/10.5194/acp-1711637-2017, 2017

Fairlie, T. D., Liu, H., Vernier, J.-P., Campuzano-Jost, P., Jimenez, J. L., Jo, D. S., Zhang, B., Natarajan, M., Avery, M. A., and Huey, G.: Estimates of Regional Source Contributions to the Asian Tropopause Aerosol Layer Using a Chemical Transport Model, J. Geophys. Res.-Atmos., 125, e2019JD031506, https://doi.org/10.1029/2019JD031506, 2020.

Garny, H. and Randel, W. J.: Dynamic variability of the Asian monsoon anticyclone observed in potential vorticity and correlations with tracer distributions, J. Geophys. Res.-Atmos., 118, 1342113433, https://doi.org/10.1002/2013JD020908, 2013.

Garny, H. and Randel, W. J.: Transport pathways from the Asian monsoon anticyclone to the stratosphere, Atmos. Chem. Phys., 16, 2703-2718, https://doi.org/10.5194/acp-16-27032016, 2016.

Gottschaldt, K.-D., Schlager, H., Baumann, R., Bozem, H., Eyring, V., Hoor, P., Jöckel, P., Jurkat, T., Voigt, C., Zahn, A., and Ziereis, H.: Trace gas composition in the Asian summer monsoon anticyclone: a case study based on aircraft observations and model simulations, Atmos. Chem. Phys., 17, 6091-6111, https://doi.org/10.5194/acp-17-6091-2017, 2017.

Gu, Y., Liao, H., and Bian, J.: Summertime nitrate aerosol in the upper troposphere and lower stratosphere over the Tibetan Plateau and the South Asian summer monsoon region, Atmos. Chem. Phys., 16, 6641-6663, https://doi.org/10.5194/acp-166641-2016, 2016.

Highwood, E. J. and Hoskins, B. J.: The tropical tropopause, Q. J. R. Meteorol. Soc., 124, 1579-1604, https://doi.org/10.1002/qj.49712454911, 1998.

He, J., Y. Zhang, T. Glotfelty, R. He, R. Bennartz, J. Rausch, and K. Sartelet: Decadal simulation and comprehensive evaluation of CESM/CAM5.1 with advanced chemistry, aerosol microphysics, and aerosol cloud interactions, J. Adv. Model. Earth Syst., 7, 110-141, https://doi.org/10.1002/2014MS000360, 2015.

Hoesly, R. M., Smith, S. J., Feng, L., Klimont, Z., JanssensMaenhout, G., Pitkanen, T., Seibert, J. J., Vu, L., Andres, R. J., Bolt, R. M., Bond, T. C., Dawidowski, L., Kholod, N., Kurokawa, J.-I., Li, M., Liu, L., Lu, Z., Moura, M. C. P., O'Rourke, P. R., and Zhang, Q.: Historical (1750-2014) anthropogenic emissions of reactive gases and aerosols from the Community Emissions Data System (CEDS), Geosci. Model Dev., 11, 369-408, https://doi.org/10.5194/gmd-11-369-2018, 2018.

Höpfner, M., Ungermann, J., Borrmann, S., Wagner, R., Spang, R., Riese, M., Stiller, G., Appel, O., Batenburg, A. M., Bucci, S., Cairo, F., Dragoneas, A., Friedl-Vallon, F., Hünig, A., Johansson, S., Krasauskas, L., Legras, B., Leisner, T., Mahnke, C., Möhler, O., Molleker, S., Müller, R., Neubert, T., Orphal, J., Preusse, P., Rex, M., Saathoff, H., Stroh, F., Weigel, R., and Wohltmann, I.: Ammonium nitrate particles formed in upper troposphere from ground ammonia sources during Asian monsoons, Nat. Geosci., 12, 608-612, https://doi.org/10.1038/s41561-019-0385-8, 2019.
Khaykin, S. M., Godin-Beekmann, S., Keckhut, P., Hauchecorne, A., Jumelet, J., Vernier, J.-P., Bourassa, A., Degenstein, D. A., Rieger, L. A., Bingen, C., Vanhellemont, F., Robert, C., DeLand, M., and Bhartia, P. K.: Variability and evolution of the midlatitude stratospheric aerosol budget from 22 years of ground-based lidar and satellite observations, Atmos. Chem. Phys., 17, 18291845, https://doi.org/10.5194/acp-17-1829-2017, 2017.

Kurokawa, J., Ohara, T., Morikawa, T., Hanayama, S., JanssensMaenhout, G., Fukui, T., Kawashima, K., and Akimoto, H.: Emissions of air pollutants and greenhouse gases over Asian regions during 2000-2008: Regional Emission inventory in ASia (REAS) version 2, Atmos. Chem. Phys., 13, 11019-11058, https://doi.org/10.5194/acp-13-11019-2013, 2013.

Lamarque, J.-F. and Emmons, L. K.: Emissions from CEDS for CMIP6, NCAR-UCAR, available at: https: //svn-ccsm-inputdata.cgd.ucar.edu/trunk/inputdata/atm/cam/ chem/emis/CMIP6_emissions_1750_2015/, last access: 1 January 2020.

Lamarque, J.-F., Emmons, L. K., Hess, P. G., Kinnison, D. E., Tilmes, S., Vitt, F., Heald, C. L., Holland, E. A., Lauritzen, P. H., Neu, J., Orlando, J. J., Rasch, P. J., and Tyndall, G. K.: CAM-chem: description and evaluation of interactive atmospheric chemistry in the Community Earth System Model, Geosci. Model Dev., 5, 369-411, https://doi.org/10.5194/gmd-5369-2012, 2012.

Lau, W. K. M., Yuan, C., Li, Z., and Li, Z.: Origin, Maintenance and Variability of the Asian Tropopause Aerosol Layer (ATAL): The Roles of Monsoon Dynamics, Sci. Rep.-UK, 8, 2045-2322, https://doi.org/10.1038/s41598-018-22267-z, 2018.

Legras, B. and Bucci, S.: Confinement of air in the Asian monsoon anticyclone and pathways of convective air to the stratosphere during the summer season, Atmos. Chem. Phys., 20, 1104511064, https://doi.org/10.5194/acp-20-11045-2020, 2020.

Liu, X., Easter, R. C., Ghan, S. J., Zaveri, R., Rasch, P., Shi, X., Lamarque, J.-F., Gettelman, A., Morrison, H., Vitt, F., Conley, A., Park, S., Neale, R., Hannay, C., Ekman, A. M. L., Hess, P., Mahowald, N., Collins, W., Iacono, M. J., Bretherton, C. S., Flanner, M. G., and Mitchell, D.: Toward a minimal representation of aerosols in climate models: description and evaluation in the Community Atmosphere Model CAM5, Geosci. Model Dev., 5, 709-739, https://doi.org/10.5194/gmd-5-709-2012, 2012.

Livesey, N. J., Filipiak, M. J., Froidevaux, L., Read, W. G., Lambert, A., Santee, M. L., Jiang, J. H., Pumphrey, H. C., Waters, J. W., Cofield, R. E., Cuddy, D. T., Daffer, W. H., Drouin, B. J., Fuller, R. A., Jarnot, R. F., Jiang, Y. B., Knosp, B. W., Li, Q. B., Perun, V. S., Schwartz, M. J., Snyder, W. V, Stek, P. C., Thurstans, R. P., Wagner, P. A., Avery, M., Browell, E. V, Cammas, J.-P., Christensen, L. E., Diskin, G. S., Gao, R.-S., Jost, H.J., Loewenstein, M., Lopez, J. D., Nedelec, P., Osterman, G. B., Sachse, G. W., and Webster, C. R.: Validation of Aura Microwave Limb Sounder $\mathrm{O}_{3}$ and $\mathrm{CO}$ observations in the upper troposphere and lower stratosphere, J. Geophys. Res.-Atmos., 113, D15S02, https://doi.org/10.1029/2007JD008805, 2008.

Livesey, N. J., Read, W. G., Wagner, P. A., Froidevaux, L., Lambert, A., Manney, G. L., Millán Valle, L. F., Pumphrey, H. C., Santee, M. L., Schwartz, M. J., Wang, S., Fuller, R. A., Jarnot, R. F., Knosp, B. W., Martinez, E., and Lay, R. R.: Version 4.2x Level 2 and 3 data quality and description document, Jet Propul. Lab., 
Tech. Rep. JPL D-33509 Rev. E, Pasadena, CA, USA, available at: https://mls.jpl.nasa.gov/data/, last access: 20 April 2020.

Ma, J., Brühl, C., He, Q., Steil, B., Karydis, V. A., Klingmüller, K., Tost, H., Chen, B., Jin, Y., Liu, N., Xu, X., Yan, P., Zhou, X., Abdelrahman, K., Pozzer, A., and Lelieveld, J.: Modeling the aerosol chemical composition of the tropopause over the Tibetan Plateau during the Asian summer monsoon, Atmos. Chem. Phys., 19, 11587-11612, https://doi.org/10.5194/acp-19-115872019, 2019.

Mårtensson, E. M., Nilsson, E. D., de Leeuw, G., Cohen, L. H., and Hansson, H.-C.: Laboratory simulations and parameterization of the primary marine aerosol production, J. Geophys. Res.-Atmos., 108, 4297, https://doi.org/10.1029/2002JD002263, 2003.

Merikanto, J., Napari, I., Vehkamäki, H., Anttila, T., and Kulmala, M.: New parameterization of sulfuric acidammonia-water ternary nucleation rates at tropospheric conditions, J. Geophys. Res.-Atmos., 12, D15207, https://doi.org/10.1029/2006JD007977, 2007.

Mills, M. J., Schmidt, A., Easter, R., Solomon, S., Kinnison, D. E., Ghan, S. J., Neely III, R. R., Marsh, D. R., Conley, A., Bardeen, C. G., and Gettelman, A.: Global volcanic aerosol properties derived from emissions, 1990-2014, using CESM1(WACCM), J. Geophys. Res.-Atmos., 121, 2332-2348, https://doi.org/10.1002/2015JD024290, 2016.

Monahan, E. C., Spiel, D. E., and Davidson, K. L.: A Model of Marine Aerosol Generation Via Whitecaps and Wave Disruption, in: Oceanographic Sciences Library, Springer Netherlands, 167174, 1986.

NCAR: CESM (The Community Earth System Model), National Science Foundation, the Department of Energy, the National Aeronautics and Space Administration, and the University Corporation for Atmospheric Research National Center for Atmospheric Research (NCAR), available at: http://www.cesm.ucar. edu/models/cesm1.2/tags/index.html\#CESM1_2_2 (last access: 1 June 2018), 2014.

NCAR/UCAR and Climate and Global Dynamics Division: Modern-Era Retrospective analysis for Research and Applications, Version 2 (MERRA2), National Center for Atmospheric Research/University Corporation for Atmospheric Research, and Climate and Global Dynamics Division, available at: https://rda. ucar.edu/datasets/ds313.3/, last access: 11 September 2020.

Neely, R., Yu, P., Rosenlof, K., B. Toon, O., S. Daniel, J., Solomon, S., and Miller, H. L.: The contribution of anthropogenic $\mathrm{SO}_{2}$ emissions to the Asian tropopause aerosol layer, J. Geophys. Res., 119, 1571-1579, https://doi.org/10.1002/2013JD020578, 2014.

Nützel, M., Dameris, M., and Garny, H.: Movement, drivers and bimodality of the South Asian High, Atmos. Chem. Phys., 16, 14755-14774, https://doi.org/10.5194/acp-16-14755-2016, 2016.

Pan, L. L., Honomichl, S. B., Kinnison, D. E., Abalos, M., Randel, W. J., Bergman, J. W., and Bian, J.: Transport of chemical tracers from the boundary layer to stratosphere associated with the dynamics of the Asian summer monsoon, J. Geophys. Res., 121, 14159-14174, https://doi.org/10.1002/2016JD025616, 2016.

Park, M., Randel, W. J., Gettelman, A., Massie, S. T. and Jiang, J. H.: Transport above the Asian summer monsoon anticyclone inferred from Aura Microwave Limb
Sounder tracers, J. Geophys. Res.-Atmos., 112, D16309, https://doi.org/10.1029/2006JD008294, 2007.

Park, M., Randel, W. J., Emmons, L. K., Bernath, P. F., Walker, K. A., and Boone, C. D.: Chemical isolation in the Asian monsoon anticyclone observed in Atmospheric Chemistry Experiment (ACE-FTS) data, Atmos. Chem. Phys., 8, 757-764, https://doi.org/10.5194/acp-8-757-2008, 2008.

Park, M., Randel, W. J., Emmons, L. K., and Livesey, N. J.: Transport pathways of carbon monoxide in the Asian summer monsoon diagnosed from Model of Ozone and Related Tracers (MOZART), J. Geophys. Res.-Atmos., 114, D08303, https://doi.org/10.1029/2008JD010621, 2009.

Park, S. and Bretherton, C. S.: The University of Washington shallow convection and moist turbulence schemes and their impact on climate simulations with the Community Atmosphere Model, J. Climate, 22, 3449-3469, 2009.

Ploeger, F., Gottschling, C., Griessbach, S., Grooß, J.-U., Guenther, G., Konopka, P., Müller, R., Riese, M., Stroh, F., Tao, M., Ungermann, J., Vogel, B., and von Hobe, M.: A potential vorticitybased determination of the transport barrier in the Asian summer monsoon anticyclone, Atmos. Chem. Phys., 15, 13145-13159, https://doi.org/10.5194/acp-15-13145-2015, 2015.

Pumphrey, H. C., Filipiak, M. J., Livesey, N. J., Schwartz, M. J., Boone, C., Walker, K. A., Bernath, P., Ricaud, P., Barret, B., Clerbaux, C., Jarnot, R. F., Manney, G. L., and Waters, J. W.: Validation of middle-atmosphere carbon monoxide retrievals from the Microwave Limb Sounder on Aura, J. Geophys. Res.-Atmos., 112, D24S38, https://doi.org/10.1029/2007JD008723, 2007.

Qie, X., Wu, X., Yuan, T., Bian, J., and Lu, D.: Comprehensive Pattern of Deep Convective Systems over the Tibetan Plateau-South Asian Monsoon Region Based on TRMM Data, J. Climate, 27, 6612-6626, https://doi.org/10.1175/JCLI-D-14-00076.1, 2014.

Randel, W. J. and Park, M.: Deep convective influence on the Asian summer monsoon anticyclone and associated tracer variability observed with Atmospheric Infrared Sounder (AIRS), J. Geophys. Res.-Atmos., 111, D12314, https://doi.org/10.1029/2005JD006490, 2006.

Santee, M. L., Manney, G. L., Livesey, N. J., Schwartz, M. J., Neu, J. L., and Read, W. G.: A comprehensive overview of the climatological composition of the Asian summer monsoon anticyclone based on 10 years of Aura Microwave Limb Sounder measurements, J. Geophys. Res.-Atmos., 122, 54915514, https://doi.org/10.1002/2016JD026408, 2017.

Sellitto, P., Sèze, G., and Legras, B.: Secondary sulphate aerosols and cirrus clouds detection with SEVIRI during Nabro volcano eruption, Int. J. Remote Sens., 38, 5657-5672, https://doi.org/10.1080/01431161.2017.1348635, 2017.

Sindelarova, K., Granier, C., Bouarar, I., Guenther, A., Tilmes, S., Stavrakou, T., Müller, J.-F., Kuhn, U., Stefani, P., and Knorr, W.: Global data set of biogenic VOC emissions calculated by the MEGAN model over the last 30 years, Atmos. Chem. Phys., 14, 9317-9341, https://doi.org/10.5194/acp-14-9317-2014, 2014.

Stroppiana, D., Brivio, P. A., Grégoire, J.-M., Liousse, C., Guillaume, B., Granier, C., Mieville, A., Chin, M., and Pétron, G.: Comparison of global inventories of $\mathrm{CO}$ emissions from biomass burning derived from remotely sensed data, Atmos. Chem. Phys., 10, 12173-12189, https://doi.org/10.5194/acp-1012173-2010, 2010. 
Tansey, K., Grégoire, J.-M., Defourny, P., Leigh, R., Pekel, J.-F., van Bogaert, E., and Bartholomé, E.: A new, global, multi-annual (2000-2007) burnt area product at $1 \mathrm{~km}$ resolution, Geophys. Res. Lett., 35, L01401, https://doi.org/10.1029/2007GL031567, 2008.

Tissier, A.-S. and Legras, B.: Convective sources of trajectories traversing the tropical tropopause layer, Atmos. Chem. Phys., 16, 3383-3398, https://doi.org/10.5194/acp-16-3383-2016, 2016.

van Marle, M. J. E., Kloster, S., Magi, B. I., Marlon, J. R., Daniau, A.-L., Field, R. D., Arneth, A., Forrest, M., Hantson, S., Kehrwald, N. M., Knorr, W., Lasslop, G., Li, F., Mangeon, S., Yue, C., Kaiser, J. W., and van der Werf, G. R.: Historic global biomass burning emissions for CMIP6 (BB4CMIP) based on merging satellite observations with proxies and fire models (1750-2015), Geosci. Model Dev., 10, 3329-3357, https://doi.org/10.5194/gmd-10-3329-2017, 2017.

van der Werf, G. R., Randerson, J. T., Giglio, L., van Leeuwen, T. T., Chen, Y., Rogers, B. M., Mu, M., van Marle, M. J. E., Morton, D. C., Collatz, G. J., Yokelson, R. J., and Kasibhatla, P. S.: Global fire emissions estimates during 1997-2016, Earth Syst. Sci. Data, 9, 697-720, https://doi.org/10.5194/essd-9-697-2017, 2017.

Vernier, J.-P., Thomason, L. W., and Kar, J.: CALIPSO detection of an Asian tropopause aerosol layer, Geophys. Res. Lett., 38, L07804, https://doi.org/10.1029/2010GL046614, 2011.

Vernier, J.-P., Fairlie, T. D., Natarajan, M., Wienhold, F. G., Bian, J., Martinsson, B. G., Crumeyrolle, S., Thomason, L. W., and Bedka, K. M.: Increase in upper tropospheric and lower stratospheric aerosol levels and its potential connection with Asian pollution, J. Geophys. Res., 120, 1608-1619, https://doi.org/10.1002/2014JD022372, 2015.

Vernier, H., Wienhold, F. G., Liu, H., Knepp, T. N., Thomason, L., Crawford, J., Ziemba, L., Moore, J., Crumeyrolle, S., Williamson, M., Berthet, G., Jégou, F., and Renard, J.-B.: BATAL: The Balloon Measurement Campaigns of the Asian Tropopause Aerosol Layer, B. Am. Meteor.. Soc., 99, 955-973, https://doi.org/10.1175/BAMS-D-17-0014.1, 2018.

Vogel, B., Günther, G., Müller, R., Grooß, J.-U., and Riese, M.: Impact of different Asian source regions on the composition of the Asian monsoon anticyclone and of the extratropical lowermost stratosphere, Atmos. Chem. Phys., 15, 13699-13716, https://doi.org/10.5194/acp-15-13699-2015, 2015.

Wang, H., Easter, R. C., Rasch, P. J., Wang, M., Liu, X., Ghan, S. J., Qian, Y., Yoon, J.-H., Ma, P.-L., and Vinoj, V.: Sensitivity of remote aerosol distributions to representation of cloud-aerosol interactions in a global climate model, Geosci. Model Dev., 6, 765-782, https://doi.org/10.5194/gmd-6-765-2013, 2013.

Waters, J. W., Froidevaux, L., Harwood, R. S., Jarnot, R. F., Pickett, H. M., Read, W. G., Siegel, P. H., Cofield, R. E., Filipiak, M. J., Flower, D. A., Holden, J. R., Lau, G. K., Livesey, N. J., Manney, G. L., Pumphrey, H. C., Santee, M. L., Wu, D. L., Cuddy, D. T., Lay, R. R., Loo, M. S., Perun, V. S., Schwartz, M. J., Stek, P. C., Thurstans, R. P., Boyles, M. A., Chandra, K. M., Chavez, M. C., Gun-Shing Chen, Chudasama, B. V, Dodge, R., Fuller, R. A., Girard, M. A., Jiang, J. H., Yibo Jiang, Knosp, B. W., LaBelle, R. C., Lam, J. C., Lee, K. A., Miller, D., Oswald, J. E., Patel, N. C., Pukala, D. M., Quintero, O., Scaff, D. M., Van Snyder, W., Tope, M. C., Wagner, P. A., and Walch, M. J.: The Earth observing system microwave limb sounder (EOS MLS) on the aura Satellite, IEEE T. Geosci. Remote S., 44, 1075-1092, https://doi.org/10.1109/TGRS.2006.873771, 2006.

Wei, W., Zhang, R., Yang, S., Li, W., and Wen, M.: Quasi-biweekly oscillation of the South Asian high and its role in connecting the Indian and East Asian summer rainfalls, Geophys. Res. Lett., 46, 14742-14750. https://doi.org/10.1029/2019GL086180, 2019.

Wu, C., Lin, Z., Liu, X., Li, Y., Lu, Z., and Wu, M.: Can Climate Models Reproduce the Decadal Change of Dust Aerosol in East Asia?, Geophys. Res. Lett., 45, 9953-9962, https://doi.org/10.1029/2018GL079376, 2018.

Wu, M., Liu, X., Yang, K., Luo, T., Wang, Z., Wu, C., Zhang, K., Yu, H., and Darmenov, A.: Modeling Dust in East Asia by CESM and Sources of Biases, J. Geophys. Res.-Atmos., 124, 8043-8064, https://doi.org/10.1029/2019JD030799, 2019.

Xu, C., Ma, Y. M., You, C., and Zhu, Z. K.: The regional distribution characteristics of aerosol optical depth over the Tibetan Plateau, Atmos. Chem. Phys., 15, 12065-12078, https://doi.org/10.5194/acp-15-12065-2015, 2015.

Yan, R.-C., Bian, J.-C., and Fan, Q.-J.: The impact of the South Asia High Bimodality on the chemical composition of the upper troposphere and lower stratosphere, Atmos. Oceanic Sci. Lett., 4, 229-234, 2011.

Yu, P., Toon, O. B., Neely, R. R., Martinsson, B. G., and Brenninkmeijer, C. A. M.: Composition and physical properties of the Asian Tropopause Aerosol Layer and the North American Tropospheric Aerosol Layer, Geophys. Res. Lett., 42, 2540-2546, https://doi.org/10.1002/2015GL063181, 2015.

Yu, P., Rosenlof, K. H., Liu, S., Telg, H., Thornberry, T. D., Rollins, A. W., Portmann, R. W., Bai, Z., Ray, E. A., Duan, Y., Pan, L. L., Toon, O. B., Bian, J., and Gao, R.-S.: Efficient transport of tropospheric aerosol into the stratosphere via the Asian summer monsoon anticyclone, P. Natl. Acad. Sci. USA, 114, 6972-6977, https://doi.org/10.1073/pnas.1701170114, 2017.

Yuan, C., Lau, W. K. M., Li, Z., and Cribb, M.: Relationship between Asian monsoon strength and transport of surface aerosols to the Asian Tropopause Aerosol Layer (ATAL): interannual variability and decadal changes, Atmos. Chem. Phys., 19, 19011913, https://doi.org/10.5194/acp-19-1901-2019, 2019.

Zender, C. S., Bian, H., and Newman, D.: Mineral Dust Entrainment and Deposition (DEAD) model: Description and 1990s dust climatology, J. Geophys. Res.-Atmos., 108, 4416, https://doi.org/10.1029/2002JD002775, 2003.

Zhang, G. J. and McFarlane, N. A.: Sensitivity of climate simulations to the parameterization of cumulus convection in the Canadian Climate Centre general circulation model, Atmos. Ocean, 33, 407-446, 1995.

Zhang, Q., Wu, G., and Qian, Y.: The Bimodality of the $100 \mathrm{hPa}$ South Asia High and its Relationship to the Climate Anomaly over East Asia in Summer, J. Meteorol. Soc. Jpn., 80, 733-744, 2002.

Zheng, B., Tong, D., Li, M., Liu, F., Hong, C., Geng, G., Li, H., Li, X., Peng, L., Qi, J., Yan, L., Zhang, Y., Zhao, H., Zheng, Y., He, K., and Zhang, Q.: Trends in China's anthropogenic emissions since 2010 as the consequence of clean air actions, Atmos. Chem. Phys., 18, 14095-14111, https://doi.org/10.5194/acp-18-140952018, 2018. 